\title{
economics-of-security.eu
}

Benedikt Goderis and Mila Versteeg

\section{Human Rights Violations After 9/11 and the Role of Constitutional Constraints}

April 2009

Economics of Security Working Paper 11

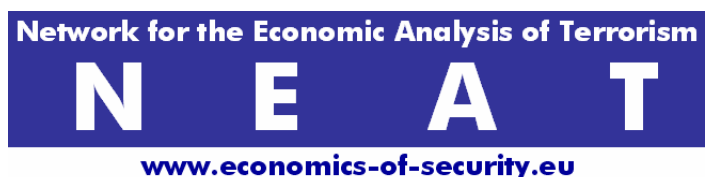




\section{Economics of Security Working Paper Series}

The Economics of Security Working Paper Series combines outputs of European Security Economics (EUSECON), a research project supported by the European Commission's Seventh Framework Programme, with outputs of the Network for the Economic Analysis of Terrorism (NEAT), which is funded by the European Commission's Directorate General for Justice, Freedom, and Security. Papers not funded by EUSECON or by NEAT can still be submitted for inclusion in this Working Paper Series.

Correct citation: Goderis, B. and Versteeg, M. (2009). "Human Rights Violations After 9/11 and the Role of Constitutional Constraints". Economics of Security Working Paper 11, Berlin: Economics of Security.

First published in 2009

(C) Benedikt Goderis and Mila Versteeg 2009

ISSN: $1868-0488$

For further information, please contact:

Economics of Security, c/o Department of International Economics, German Institute for Economic Research (DIW Berlin), Mohrenstr. 58, 10117 Berlin, Germany.

Tel: $+49(0) 3089789-277$

Email: neat@diw.de

Website: www.economics-of-security.eu 


\title{
Human Rights Violations after 9/11 and the Role of
}

\author{
Constitutional Constraints*
}

\author{
Benedikt Goderis ${ }^{\dagger}$ \\ University of Oxford
}

and

\author{
Mila Versteeg ${ }^{\ddagger}$ \\ New York University and \\ University of Oxford
}

\section{March 2009}

\begin{abstract}
After 9/11, the United States and its allies took measures to protect their citizens from future terrorist attacks. While these measures aim to increase security, they have often been criticized for violating human rights. But violating rights is difficult in a constitutional democracy with separated powers and checks and balances. This paper empirically investigates the effect of the post-9/11 terror threat on human rights. We find strong evidence of a systematic increase in rights violations in the U.S. and its ally countries after $9 / 11$. When testing the importance of checks and balances, we find that this increase is significantly smaller in countries with independent judicial review (counter-majoritarian checks), but did not depend on the presence of veto players in the legislative branch (majoritarian checks). These findings have important implications for constitutional debates on rights protection in times of emergency.
\end{abstract}

Keywords: human rights, terrorism, 9/11, checks and balances, constitutions, constitutional courts

JEL Classification: K19, D72, F52

\footnotetext{
* We would like to thank in particular Eric Posner and Matthew Stephenson for many helpful comments. We also thank Micael Castanheira, Paul Collier, Sivan Frenkel, Denis Galligan, Scott Gates, Rizwaan Jameel Mokal, Lewis Kornhauser, Dennis Mueller, Torsten Persson, Richard Pildes, Nicolas van de Sijpe, Rick van der Ploeg, and conference and seminar participants at Harvard University, New York University, Tilburg University, University College London, University of Oxford, the DIW Berlin/European Commission Second Workshop of the Network for the Economic Analysis of Terrorism (NEAT), the Annual Conference of the Netherlands Network of Economics, and the CESifo 2nd Workshop on Political Economy for helpful comments.

$\dagger$ Department of Economics, University of Oxford, Manor Road, Oxford OX1 3UQ, U.K.

Email: Benedikt.Goderis@economics.ox.ac.uk.

$\ddagger$ Centre for Socio-Legal Studies, Faculty of Law, and Balliol College, University of Oxford, Manor Road, Oxford OX1 3UQ, U.K. Email: Mila.Versteeg@balliol.ox.ac.uk.
} 


\section{Introduction}

After 9/11, the governments of the United States and its allies took a range of counterterrorism measures to protect their citizens from future terrorist attacks. ${ }^{1}$ While these measures aim to increase domestic security, they have often been criticized for violating human rights. Coercive interrogation, ethnic profiling, interception of communications and preventive arrests and detention may be necessary to fight terrorism but are oftentimes in violation of a country's commitment to human rights. A common response to such criticisms is that there is a tradeoff between security and liberty and that in times of national emergency, such as the aftermath of $9 / 11$, the security-liberty balance shifts in favor of security (Posner and Vermeule (2008), Posner (2007)). And indeed, opinion polls suggest that people have been willing to trade rights against security (Davis and Silver (2004), Bozolli and Müller (2008), Cole and Dempsey (2006)). Moreover, the extensive media coverage of a few big human rights controversies, such as the indefinite pre-trial detentions in Belmarsh prison in London and Guantánamo Bay in Cuba, suggests that rights have been violated after 9/11. But are these isolated incidents or has there been a systematic deterioration in the human rights practices of the West?

Violating human rights is not easy in a constitutional democracy with separated powers and checks and balances (Montesquieu (1748), Madison (1787), Hamilton and Madison (1788)). Democratic governments may be constrained by, what we will call, majoritarian and counter-majoritarian checks and balances. Majoritarian checks play out in the rela-

\footnotetext{
${ }^{1}$ The U.S., in the first year after the attack, adopted 53 resolutions and 68 acts, amongst which the 2001 PATRIOT Act (Library of Congress (2002)). Within a month, Canada had drafted a 186 page Anti-Terrorism Act, which was signed into law in December 2001 (Roach (2003)). Australia, since 9/11, introduced 40 pieces of counter-terrorism legislation (Australian Human Rights Commission (2008)). Germany, in 2002, adopted a security package that amended "nearly one hundred regulations in seventeen different statutes and five statutory orders" (Scheppele (2004)). The U.K. adopted comprehensive counterterrorism bills in 2001, 2005, 2006 and 2008. And all E.U. member states incorporated a common definition of terrorism into their criminal laws as a result of the 2002 E.U. Framework Decision on Combating Terrorism (Scheppele (2004)).
} 
tionship between the executive and legislative branches. Such checks have traditionally been thought of as the power that the legislative and executive branches exercise over each other (Hamilton and Madison (1788)). Yet today, the relationship between political parties within those branches is arguably more important than the constitutional arrangements between the branches as such (Levinson and Pildes (2006), Tsebelis (2002)). Particularly, if there is an opposition party in the legislative branch that is large enough to exercise veto power, it may constitute an effective check on the executive. This veto power is exercised to further the interest of the majority of voters. Political parties, after all, seek electoral support and re-election. Therefore, when the majority of voters want to trade rights against security, veto players remain silent. But when the majority opposes counterterrorism measures, veto players are likely to use their vetoes. While majoritarian checks may not prevent a 'tyranny of the majority', they do prevent 'tyranny of the executive'. One may thus expect that countries with majoritarian checks have seen fewer post-9/11 rights violations than countries without majoritarian checks, but only to the extent that violations were contrary to the wishes of the majority.

Counter-majoritarian checks are exercised by the judicial branch. If an independent judicial branch is equipped with the power of judicial review, it may enforce the nations constitutional precommitments to rights and invalidate laws that violate the constitution. When using this power, the judiciary guarantees a minimum level of rights protection regardless of what the majority wants. It keeps majorities to their precommitments, even when, at a later time, majorities favor security over rights (Elster (1979, 1993), Holmes (1988)). One may therefore expect that countries with independent judicial review have seen fewer rights violations after 9/11 than countries without such review.

In this paper we empirically analyze these issues. We use an ordered probit model and differences-in-differences estimation for 152 countries between 1978 and 2006 to investigate the effect of the post-9/11 terror threat on human rights. We find strong evidence of a systematic increase in rights violations in the U.S. and its ally countries after $9 / 11$. When testing the importance of checks and balances, we find that this increase is significantly smaller in countries with independent judicial review (counter-majoritarian checks), but 
did not depend on the presence of veto players in the legislative branch (majoritarian checks).

Our findings have direct implications for constitutional debates on rights protection in times of emergency. After $9 / 11$, scholars have stood divided on whether a nation should stick to its precommitments to human rights (Dworkin (2003), Levinson (2002)) or whether flexible security-liberty tradeoffs should prevail (Posner (2007), Posner and Vermeule (2008)). An important view is that in times of emergency, majorities panic (Ignatieff (2004), Stone (2004), Ackerman (2004)) and democracies fail to take account of minority interests (Cole (2003), Sunstein (2004)). In these times, it is best to stick to precommitments. The opposite view is that a constitution is 'not a suicide pact'2 and that a constitution that 'will not bend will break' (Posner (2007)). A government may have to compromise rights today to save life in the future (Posner and Vermeule (2008)). This paper is the first to empirically establish that, overall, Western countries did not stick to their precommitments after $9 / 11$. Whether the tradeoff was 'real' or 'imagined', rights have been traded against (at least the perception of) security. While there was a strong rights deterioration in the first four post-9/11 years, rights improved again in 2005 and 2006. This may indicate that the fear of a 'ratchet effect' (Posner and Vermeule (2008)), or that when bending the constitution, it will never bend back, is not justified.

But we also find that in countries with strong judicial review, courts prevented such rights violations in the first place. This finding is important for those divided on the appropriate institutional competences of different branches in times of emergency. Those who favor flexible balancing focus on the executive: the executive is best equipped to act fast and deal flexibly with security threats. Courts should not exercise review but defer to the executive (Posner and Vermeule (2008), Yoo (2005)). Those who favor precommitments focus on the judiciary: courts should scrutinize security policies and invalidate measures that violate rights (Barak (2002), Koh (2002)). Those who favor a middle way focus on the legislature: legislatures should make sure that security measures represent the wishes of the majority of the people. Judicial review should serve only to strengthen

\footnotetext{
${ }^{2}$ Justice Goldberg in Kennedy v. Mendoza Martinez (372 U.S. 144 [1963]).
} 
this political process (Sunstein (2004), Issacharoff and Pildes (2004)). Our results suggest that one's normative position about institutional competences directly implicates rights. Unlike sometimes asserted by their opponents, legislatures clearly do worse in protecting rights than the judiciary. And in contrast with claims that judges are unable to exercise review in times of crises (Ackerman (2004), Posner (2007)) courts did protect rights after 9/11. Cicero's maxim 'silent enim leges inter arma' (during war law is silent) did not apply to constitutional law after 9/11 (Cicero (52 BC). Especially courts in countries with protective Bills of Rights have been powerful. Yet, judicial review to strengthen legislative involvement, as predominant in the U.S. Supreme Court, is unlikely to protect rights, as legislatures have allowed for significant right violations. ${ }^{3}$ The ineffectiveness of legislative checks also tells us something about the executive. Apparently, executives were not trying to take advantage of citizens or pursuing partisan objectives, but violated rights on the majority's account. If not, legislatures would have vetoed such a course of action.

But our findings are important beyond the post-9/11 security debates. While constitutionalism and judicial review are promoted around the world, there is little evidence that they indeed constrain government (Schauer (2008)). In fact, the conventional faith in judicial review as the main mechanism for protecting rights (Dworkin (1977)) is increasingly challenged in legal theory and replaced by a renewed faith in legislatures, who facilitate deliberation among disagreeing parties (Waldron (1999)). Economists have paid attention to the economic effects of the structural part of the constitution, such as the electoral and governmental system (Persson and Tabellini (2003)). Yet, the part of the constitution that entrenches precommitments to rights has received much less empirical attention. Only one study considers the general cross-country effect of judicial review on rights (La Porta et al. (2004)), while there is only one country study on judicial review after 9/11 (Epstein et al. (2005)). This paper is moreover the first to empirically consider judicial review together

\footnotetext{
${ }^{3}$ The U.S. Supreme Court in times of war does not directly enforce constitutional rights (Rehnquist (1998)), but only requires presidential action to be authorized by Congress (Issacharoff and Pildes (2004)). This process-based framework, enforcing the separation of powers rather than the Bill of Rights, is expressed in Justice Jackson's opinion in Youngstown Sheet \& Tube Co. v. Sawyer (343 U.S. 579 [1952]).
} 
with the actual precommitments, or the text of the constitution. Using data based on our coding of the Bill of Rights of 152 countries, we find that protective constitutional rights help independent courts in exercising review. But without judicial enforcement, constitutional rights are not effective, thus defeating the notion of 'popular constitutionalism' (Kramer (2004)), or the idea that the people themselves will enforce the constitution.

The rest of this paper is structured as follows. Section 2 describes the methodology and data. Section 3 reports the results of estimating the effect of $9 / 11$ on human rights. Section 4 investigates whether this effect depends on checks and balances. Section 5 reports various robustness checks and addresses endogeneity and serial correlation. Section 6 concludes.

\section{Methodology and Data}

In this section we describe our econometric model and the variables used in estimation. The effect of the (perceived) post-9/11 terror threat on human rights is analyzed using the following ordered probit model:

$$
\begin{aligned}
& y_{i, t}^{*}=\alpha t_{i}+\beta p_{t}+\delta\left(t_{i} \cdot p_{t}\right)+\sum_{k=1}^{l} \theta_{k} y_{i, t-k}+\gamma^{\prime} z_{i, t}+\varepsilon_{i, t} \\
& y_{i, t}=j \text { if } \lambda_{j-1}<y_{i, t}^{*} \leq \lambda_{j}
\end{aligned}
$$

where the subscripts $i=1, \ldots N$ and $t=1, \ldots T$ index the countries and years in the panel dataset used for estimation. $y_{i, t}$ represents an indicator of human rights violations with an ordinal scale $(j=1,2, \ldots, M), y_{i, t}^{*}$ is an underlying latent variable, and the $\lambda_{j}$ 's are cut-off values. The probability that the indicator of human rights violations takes a value of $j$ is the probability that the latent variable $y_{i, t}^{*}$ takes a value between $\lambda_{j-1}$ and $\lambda_{j}{ }^{4}$

We evaluate the impact of the post-9/11 terror threat using a differences-in-differences estimator. Hence, we identify a "treatment group" of countries that was exposed to an increased terror threat after $9 / 11$ and a "control group" that was not exposed. $t_{i}$ is a

\footnotetext{
${ }^{4}$ Following the previous literature, we compute robust standard errors clustered by country to account for heteroskedasticity and within-country serial correlation in the error terms.
} 
treatment group specific effect, included to account for average permanent differences in rights violations between treatment and control (i.e. differences that are unrelated to 9/11). $p_{t}$ is a period specific effect, included to control for post- $9 / 11$ changes in rights violations that are common to the treatment and control groups and hence unrelated to $9 / 11 . p_{t}$ takes a value of one for the year 2001 and all subsequent years, and zero otherwise. The coefficient $\delta$ of the interaction term between $t_{i}$ and $p_{t}$ captures how the effect of the post9/11 period differs between the treatment and the control group and therefore measures the true effect of the treatment, i.e. the true effect of the post-9/11 terror threat on human rights. The aim of our empirical analysis is twofold. We first test the effect of the post-9/11 terror threat on human rights, hence we attempt to find a good estimate of $\delta$. We then investigate whether this effect occurs conditional on a country's checks and balances.

Following the empirical human rights literature ${ }^{5}$, we also include lags of the dependent variable and a vector $z_{i, t}$ of control variables: log GDP per capita, GDP per capita growth, democracy, log population, and civil war. As we show in our sensitivity analysis, our results are robust to additional controls used in the literature, including trade, interstate war, a post cold war dummy and regional dummy variables. These variables are not included in our baseline specifications because they were either not robustly significant or severely lowered the number of observations. Our dataset consists of all countries and years for which data are available, and covers 152 countries between 1978 and 2006. Table 1 reports summary statistics and data sources for the variables used in estimation. Next, we discuss how the key components of equations (1) and (2) were constructed.

\subsection{Measuring human rights}

In recent decades, political scientists have developed several indicators of government repression of human rights. The most commonly used one is the "political terror scale" (Gibney, Cornet and Wood (2008)) which measures political violence and terror on a 1 to 5 ordinal scale. Political terror ranges from 1: "Countries under secure rule of law,

\footnotetext{
${ }^{5}$ See for example Dreher, Gassebner and Siemers (forthcoming), Hafner-Burton and Tsutsui (2005, 2007), Poe and Tate (1994).
} 
people not imprisoned for their view and torture rare or exceptional. Political murders extremely rare." to 5: "Terror expanded to the whole population. Leaders place no limits on the means or thoroughness with which they pursue personal or ideological goals." 6 The political terror scale contains two indicators that were constructed using the same coding methodology. The first ("pters") is based on the yearly U.S. State Department Country Reports on Human Rights Practices, while the second ("ptera") draws from the yearly Amnesty International country reports. The political terror scale is available for 183 countries from 1976 until 2006. Figure 1 (solid line) shows the average pters scores for the balanced sample of 95 countries for which we have data since 1981.

Cingranelli and Richards (2008) have recently developed an alternative set of indicators, based on both the U.S. State Department and Amnesty International reports. The CIRI dataset contains not only aggregate measures of government repression but also thirteen disaggregated measures that capture specific rights for 200 countries between 1981 and 2006. The aggregate physical integrity rights index ("physint"), just as the two political terror scale variables, captures the type of rights that have most likely been affected by post9/11 counter-terrorism initiatives. The index equals the sum of four sub-indices ("torture", "extrajudicial killing", "political imprisonment", and "disappearance") and ranges from 0 (full government respect for these rights) to 8 (no government respect for these rights). ${ }^{7}$ In our analysis, we use the pters and ptera indicators, as well as the physint indicator as alternative measures of human rights violations. ${ }^{8}$

Both the political terror scale and the CIRI indicators measure actual rights practices and do not include de jure, or constitutional, rights. However, CIRI only captures rights abuses by state actors against citizens on the state-territory. By contrast, the political terror scale also only captures abuses by state actors, but does not strictly limit itself to citizens (although it takes into account the portion of the population that is affected) and

\footnotetext{
${ }^{6}$ See the notes to Table 1 for a full explanation of the five levels of political terror.

${ }^{7}$ All CIRI indicators were rescaled so that higher scores correspond to more rights violations.

${ }^{8}$ The correlations between pters, ptera and physint are $0.79,0.72$ and 0.64 , respectively. Maddala and $\mathrm{Wu}(1999)$ panel unit root tests strongly reject a unit root for all three measures. This suggests that the series are $\mathrm{I}(0)$ and hence running the specification in equations (1) and (2) in levels is appropriate.
} 
while it "for the most part focuses on political violence that a state carries out within its own territorial borders" it uses "common sense" on matters like Guantánamo Bay.

\subsection{Identifying countries at risk}

After 9/11, the U.S. and many of its allies took counter-terrorism measures. This was partly due to a belief that terror threats had gone up in all these countries, consistent with Bin Laden's fatwa's in which he threatened not just the U.S. but also its allies. But counter-terrorism measures were also taken as part of a broad international support for the U.S. led "war on terror". The strength of this support already appeared the day after the 9/11 attacks, when NATO for the first time invoked article 5 of its charter, declaring that the atrocities were an attack on all 19 member states. Or as former German Chancellor Schroeder put it: "They were not only attacks on our friends in America, but also against the entire civilized world, against our own freedom, against our own values". Hence, increased terror threats at home and abroad led U.S. allies to adopt counter-terrorism laws. New warnings from Al-Qaeda in response to the wars in Afghanistan and Iraq further increased fears, especially in countries that participated in the wars.

We use two sets of U.S. ally groups to evaluate the impact of the post-9/11 terror threat on rights. The first includes the U.S. and its post-9/11 allies in the war on terror. Since the terror threat and thus the need for counter-terrorism may depend on a country's level of support, we distinguish between countries that deployed troops in Afghanistan and/or Iraq and countries that provided material assistance (equipment, helicopters, fuel, transport, supplies) or non-material assistance (use of airspace, naval bases, strategic support).

Although military support for the war on terror probably is a good indicator of countries' exposure to terror threats, it may be endogenous. For example, regimes that give low weight to human rights may also be more likely to participate in the war on terror. We return to this issue in section 5 when we extensively address endogeneity. However, our discussion of the post-9/11 terror threat suggests a second set of treatment variables that is based on military alliances prior to $9 / 11$ and hence suffers less from endogeneity. In 
particular, we use several variables that identify U.S. military allies in 2000. Since closer allies may face more severe threats, we distinguish between different levels of military commitment. The countries with the highest commitment to the U.S. are the NATO members, who agreed to mutual defence in response to an attack by any external party. A second and third group of pre-9/11 allies include the "major non-NATO U.S. allies" and the members of the Euro-Atlantic Partnership Council (EAPC). ${ }^{9}$ Finally, we consider several other U.S. formal military alliances. ${ }^{10}$

Table 2 lists all the pre- and post-9/11 U.S. ally groups. 60 of the 152 countries in our samples are included in one or more groups. Figure 1 shows the average pters scores for the balanced sample of 95 countries for which we have data since 1981. The dashed and dotted lines correspond to the 32 U.S. allies and the 63 non-U.S. allies in the balanced sample, respectively. Although these simple averages should not be taken as evidence of causality, the average increase in rights violations in U.S. ally countries after 2000 is clearly consistent with an adverse effect of $9 / 11$ on human rights in these countries.

\section{Estimating the Effect of 9/11 on Human Rights}

In Tables 3 and 4, we report the results of estimating the ordered probit model described in equations (1) and (2). Table 3, columns (1) to (3), show the specifications in which we use the countries that deployed troops in both Afghanistan and Iraq for our three indicators of human rights violations (pters, ptera and physint). The interaction term of the "U.S. allies" indicator and the period specific effect "(2001-2006)" enters with a positive sign and is statistically significant at 5 percent in all three specifications. This is consistent with the

\footnotetext{
${ }^{9}$ Major non-NATO allies are countries legally designated by the U.S. government as exceptionally close allies that have strategic working relations with American forces. The EAPC was created in 1997 for dialogue and consultation on political and security-related issues.

${ }^{10}$ The Correlates of War Formal Interstate Alliance Dataset (Gibler and Sarkees (2004)) documents bilateral defense alliances with Australia, Canada, Japan and the Philippines, a bilateral entente alliance with South Korea, and a multilateral defense alliance with all member states of the Organization of American States (OAS).
} 
hypothesis that the post-9/11 terror threat has led to an increase in human rights violations in the countries that supported the U.S. in the war on terror. To obtain an estimate of the size of the effect, we also report the change in the probability of each outcome (in \% points) if the interaction term increases from 0 to $1 .{ }^{11}$ Conditional on having been in the regime with the lowest degree of rights violations ( 1 for pters and ptera and 0 for physint) in the previous year, the probability of a U.S. ally country staying in that regime falls by 7.9 (pters), 10.0 (ptera), or $12.1 \%$ points (physint) for each of the post-9/11 years. This changed probability for each year indicates a substantial increase in the number of cases where rights violations in U.S. ally countries went up during the period 2001-2006. Hence, the effect is not only significant, but also sizeable. The lower probability of being in the best rights regime is for the most part offset by a higher probability of being in the next best rights regime, with the next one to three regimes taking up the residual. This indicates that the effect is mostly explained by changes from one regime to the next. ${ }^{12}$

In Table 3, columns (4) to (6), we rerun the specifications of columns (1) to (3) but we now use the countries that deployed troops in Afghanistan or Iraq, or in both. This more than doubles the number of treatment observations. Again, the interaction term of

\footnotetext{
${ }^{11}$ We set the variables "U.S. allies" and "(2001-2006)" at 1 and the two lagged dependent variables, "Human rights violations $t_{t-1}$ " and "Human rights violations $t_{t-2}$ ", at the best possible score (1 for pters and ptera and 0 for physint), which for many U.S. allies was the actual score in the year before 9/11. All other regressors were set at their median value in 2000 for the treatment countries in our sample.

${ }^{12}$ Most U.S. allies in 2000 were in the second best regime (although almost all regimes were present in at least one of the countries). Therefore, we also calculated the marginal effects when setting the two lagged dependent variables at the second best possible score. Again, we find that the probability of U.S. allies being in the best regime in the next period goes down, but now this is for the most part offset by a higher probability of being in the third best regime. Examples of countries that went from a pters score of 1 (secure rule of law, no political imprisonment, torture rare or exceptional) in 2000 to a pters score of 2 (limited political imprisonment, torture exceptional, murders rare) after 9/11 are Australia, Austria, Canada, Czech Republic, France, Germany, Japan, Poland, Portugal and Slovak Republic. An example of a country that went from 1 in 2000 to 3 (extensive political imprisonment, murders may be common, unlimited detention, with or without trial, for political views accepted) in 2002 is Spain. Countries that went from 2 to 3 are Albania, Armenia, Bulgaria, Korea, Moldova, and Romania.
} 
the U.S. allies indicator and the period specific effect (2001-2006) enters with a positive sign in all three specifications and is significant at 5 percent for pters and ptera and at 1 percent for physint. The size of the coefficients and the marginal effects is slightly smaller than in columns (1) to (3). To investigate whether the effect of $9 / 11$ depends on a country's level of support for the war on terror, we reran these specifications with separate treatment variables for troop deployment in both Afghanistan and Iraq, and troop deployment in either Afghanistan or Iraq. In all three specifications, the difference between the coefficients for both groups was insignificant, hence suggesting that pooling the two groups is appropriate. In the remainder of this paper we therefore use countries that deployed troops in Afghanistan or Iraq, or in both, as the post-9/11 group of U.S. allies. ${ }^{13}$

In Table 4, we use treatment variables that are based on military alliances prior to the 9/11 attacks. Columns (1) to (3) show the specifications in which we use just the countries that were members of NATO in 2000, while columns (4) to (6) show the specifications in which we use not only NATO member countries, but also countries that were either EAPC members, major non-NATO U.S. allies, or bilateral U.S. allies in $2000 .{ }^{14}$ Our finding that the post-9/11 terror threat has led to an increase in human rights violations in U.S. ally countries is robust to using these alternative treatment variables. The interaction term of the U.S. allies indicator and the period specific effect (2001-2006) again enters with a positive sign in all six specifications and is statistically significant at 5 percent in four of them, while significant at 10 percent in the other two. ${ }^{15}$ We reran the specifications of Table 4, columns (4) to (6), with separate treatment variables for each of the groups, but did not find any significant difference between the effect for NATO members and the effects for the other three groups. In the remainder of the paper we therefore use their common

\footnotetext{
${ }^{13}$ We found no effect of $9 / 11$ in countries that did not send troops but provided material or non-material assistance. We therefore excluded these countries from our treatment group.

${ }^{14}$ The pre-9/11 and post-9/11 U.S. ally groups partly overlap. The correlation between NATO membership and troop deployment in Afghanistan and Iraq is 0.48 , while the correlation between the larger group of pre-9/11 U.S. allies and troop deployment in Afghanistan and/or Iraq is 0.78.

${ }^{15}$ The slightly lower level of significance in the latter two specifications is probably due to the lower number of countries included in NATO, reducing the number of treatment observations to around 100.
} 
aggregate as the pre-9/11 group of U.S. allies ("Nato Plus"). ${ }^{16}$

We now turn to the other variables in Tables 3 and 4 . First, the treatment group specific effect, captured by the coefficient of the variable "U.S. allies", is always negative and significant, indicating that U.S. allies on average have lower levels of rights violations than other countries. The period specific effect, captured by the coefficient of the variable "(2001-2006)", is always positive and in half of the specifications significant, suggesting that rights violations on average have gone up after 2000. The two lags of the dependent variable both enter with a positive sign and are always statistically significant at 1 percent, consistent with the notion that human rights are relatively persistent over time. ${ }^{17}$ The other control variables also enter with the expected signs, while the coefficients are almost always highly significant. In particular, higher levels and growth rates of GDP per capita are associated with lower degrees of rights violations. More democratic countries also tend to have more respect for human rights. In contrast, countries with larger populations and countries that experience civil war have significantly worse rights regimes.

\subsection{Related Questions}

Having found that 9/11 led to a systematic and sizable increase in human rights violations in U.S. ally countries, we now turn to some related questions. First, we investigate possible effects in Muslim states, as some of them took counter-terrorism measures to prevent terrorists from using their territories as "safe havens", and in autocratic states, as it is sometimes argued that their leaders used the war on terror as a justification for repressive

\footnotetext{
${ }^{16}$ We did not find any 9/11 effect in member countries of the only other formal U.S. alliance in 2000 , the OAS. This is not surprising as the OAS collective defense treaty was last invoked by Argentina during the 1982 Falkland war. At the time, the U.S. did not respond and aligned itself with the U.K. instead, effectively turning the treaty into a dead letter. We exclude the OAS members from our treatment group.

${ }^{17}$ Our lag order selection was based on Akaike's Information Criterion (AIC) and Schwarz's Bayesian Information Criterion (BIC). We only included the lags which substantially lowered the AIC and BIC values (see Verbeek, 2000, p. 254). As part of our sensitivity analysis in section 5, we show that our results are robust to including only 1 lag (as is common in the literature) or 5 lags (the ones that are significant).
} 
legislation that curtails civil liberties. ${ }^{18}$ Yet, we do not find any evidence of such effects. ${ }^{19}$

Second, using the four sub-indices of the physical integrity rights index ${ }^{20}$ (torture, extrajudicial killings, political imprisonment and disappearances), we find that the $9 / 11$ effect is mainly driven by torture and to a lesser extent political imprisonment, while disappearances and extrajudicial killings seem less important. ${ }^{21}$ Given these findings, we constructed a new physical integrity rights index that equals the sum of the sub-indices for torture and political imprisonment only. The index ranges from 0 (full government respect for these two rights) to 4 (no government respect for these rights). In the next section, we use this index ("physint_tp") instead of the variable physint as one of our three indicators of human rights violations (the other ones being pters and ptera).

Third, we investigate whether the adverse effect of $9 / 11$ varies across years. The results indicate that rights violations substantially increased during the years 2001 to 2004 but decreased again in 2005 and 2006. A possible explanation for these findings is that the perceived threat of new terrorist attacks went down after reaching its peak in the four years following $9 / 11$, thus lowering the need for counter-terrorism. But it is also possible that violations in the first four years after 9/11 eroded popular support for counter-terrorism. In both cases, however, the effect of $9 / 11$ has not necessarily died out. Since many of the counter-terrorism laws are still in place, new systematic rights violations may occur in the future, especially in the unfortunate event of new terrorist attacks.

Finally, we investigate whether the $9 / 11$ effect extends beyond countries that experienced a terrorist attack within their own borders. Dreher, Gassebner and Siemers (forth-

\footnotetext{
${ }^{18}$ Zimbabwe's President Mugabe, for instance, justified the 2007 Interception of Communications Act by pointing at similar laws in the West.

${ }^{19}$ We found no effect of $9 / 11$ in countries where at least $25 \%, 50 \%$ or $75 \%$ of the population is Muslim (data from Barro and McCleary (2005)) and if anything, rights improved rather than deteriorated in autocratic states (states with a minimum score of either $6,7,8$, or 9 on the Polity IV autocracy scale).

${ }^{20}$ The pairwise correlations between the sub-indices range from 0.39 to 0.59 .

${ }^{21}$ In addition to these negative liberties, which are most likely to be affected, we also tested whether 9/11 affected positive liberties. Using the CIRI "empowerment rights index", which captures freedom of movement, freedom of speech, workers' rights, political participation and freedom of religion, we find no evidence that this is the case.
} 
coming) find evidence of a negative relationship between domestic terrorist attacks and respect for rights. Using data from the Global Terrorism Database (LaFree and Dugan (2008)), we construct dummy variables for more than zero, more than ten, more than twenty and more than fifty terrorism fatalities in a country in a given year and add these variables to the specifications in Tables 3 and 4 . For sensitivity, we repeat this exercise using a variable that captures the number of major terrorist attacks (50 or more fatalities). While we find evidence of an effect of domestic terrorist attacks on rights, consistent with Dreher, Gassebner and Siemers, the coefficients of the interaction between U.S. allies and (2001-2006) either marginally change or do not change at all when adding the variables. Hence, the effect of $9 / 11$ on rights is equally strong once we control for domestic terrorism.

Even though our findings are robust to controlling for domestic attacks, the effect of 9/11 may still be larger in treatment countries that experienced large terrorist attacks at home over the period 2001 till 2006. To investigate this possibility, we identify treatment countries that experienced one or more major terrorist attacks between 2001 and $2006 .^{22}$ We then test whether the effect of $9 / 11$ was significantly larger in these countries. With the exception of the U.S., we find no evidence that this is the case. Clearly, as 9/11 occurred on U.S. territory, its effect on rights was larger in the U.S. than elsewhere. Since this difference is unlikely to be explained by checks and balances, we exclude the U.S. from our estimation samples in the next section. ${ }^{23}$

\section{Do Checks Matter?}

Having established that the post-9/11 terror threat led to a significant increase in human rights violations, we now investigate whether this increase was smaller in countries with stronger checks and balances.

\footnotetext{
${ }^{22}$ These are the U.S. (2001), Korea (2003), Philippines (2001), Russia (2002, '03, '04) and Spain (2004).

${ }^{23}$ Pters already excludes the U.S. as its State Department does not report on its own country.
} 


\subsection{Counter-majoritarian Checks}

To test the effect of counter-majoritarian checks, we first divide the countries in our sample according to whether or not they have independent judicial review, i.e. a constitutional or supreme court that is politically independent and has the power to invalidate laws that violate the constitution. As an indicator of independent judicial (or constitutional) review, we construct a dummy variable based on indicators of judicial review and judicial independence. The indicator of judicial review is based on Maddex (2007) and is an update of the indicator used by La Porta et al. (2004). The indicator identifies three categories: full judicial review, limited judicial review and no judicial review. ${ }^{24}$ The indicator of judicial independence was taken from La Porta et al. (2004) and was computed as the normalized sum of three variables. The first two variables capture the tenures of supreme court judges and administrative court judges. These variables take a value of zero if tenure is less than six years, one if tenure is more than six years but not life-long and two if tenure is life-long. The third variable captures case law and is a dummy which takes a value of one if judicial decisions are a source of law and zero otherwise. La Porta et al. (2004) argue that a life-long tenure makes judges both less susceptible to political pressure and less likely to have been selected by the government currently in office. In addition, case law also increases judicial independence, as the binding power of prior judicial decisions limits the ability of governments to influence judges in specific circumstances. Using the indicators of judicial review and judicial independence, we construct a dummy variable for independent judicial review. This dummy takes a value of one if a country has full judicial independence (i.e. life-long tenure for supreme court and administrative court judges, as well as case law) and limited or full judicial review, and zero otherwise. ${ }^{25}$ For the 191

\footnotetext{
${ }^{24}$ Maddex (2007) identifies two additional categories. The first, "de facto review", includes Angola and Bhutan, which are not in our sample due to missing data. The second, "technically no review", includes Israel, New Zealand and the United Kingdom (U.K.). As the constitution in these countries is hardly more than an ordinary law that can be changed by parliament, we classify these countries as having no judicial review. However, we test the robustness of our results when classifying them as having judicial review.

${ }^{25}$ We include both countries with full and limited judicial review, as limited powers of judicial review are not necessarily an obstacle to an independent court wishing to excercise review. Most famously, the U.S.
} 
treatment observations in the common sample of Tables 3 and 4 for which we have data on judicial review and independence, the dummy is one in 78 cases and zero in 113 cases.

We now estimate the impact of independent judicial review on the $9 / 11$ effect we identified in the previous section. Table 5, column (1), augments the specification of Table 3, column (4), with the independent judicial review dummy (ijr) by itself and interacted with each of the variables U.S. allies, (2001-2006), and U.S. allies * (2001-2006). The coefficient of the variable U.S. allies * (2001-2006), which now captures the effect of $9 / 11$ in countries with no independent judicial review, is positive and statistically significant at 1 percent. The size of the coefficient is considerably larger than before, which suggests that countries with no independent judicial review have seen a more severe increase in rights violations than other countries. The coefficient of the interaction term between U.S. allies * (2001-2006) and independent judicial review corresponds to the difference between the 9/11 effect in countries without independent judicial review and the 9/11 effect in countries with independent judicial review. The coefficient is negative and statistically significant at 1 percent, which indicates that the effect of $9 / 11$ on human rights is significantly smaller in countries with independent judicial review. The linear combination of the coefficients of U.S. allies * (2001-2006) and its interaction with independent judicial review points at a statistically insignificant net effect of -0.17 in countries with independent judicial review. ${ }^{26}$ This suggests that independent judicial review fully mitigated the adverse effect of $9 / 11$ on human rights. Table 5, columns (2) and (3), report the results for subsamples without and Supreme Court decided in Marbury v. Madison (5 U.S. 137 [1803] that it could excercise review, while the constitution was arguably silent on this power. Similar examples of courts enlarging their powers of judicial review are present in Israel (where the court in 1995 decided it could excercise review), Denmark (where the court in 1996 decided that it would more frequently excercise review) and India (where the court found that it could decide which part of the constitution cannot be amended by parliament). This justification for our classification is confirmed empirically as we find no difference between the effects of independent courts with a weak mandate of review and independent courts with a full mandate of review.

${ }^{26}$ Although this net effect is not significant, its negative sign could suggest a small degree of misspecification. But it could also reflect that $9 / 11$ has led to a globally coordinated effort among judges to challenge executive unilateralism and has given rise to a new judicial activism (Benvenisti (2008)). If true, judges may have been more protective of rights than they would have been in the absence of 9/11. 
with independent judicial review, respectively. The results again imply that the increase in rights violations only occurred in countries without independent judicial review. We next repeat the specifications of Table 5, columns (1) to (3), but using the pre-9/11 instead of the post-9/11 allies. The results, reported in Table 5, columns (4) to (6), are very similar and the coefficients are again significant, although at lower levels than before.

Table 6, panels A and B, show the estimation results for all three dependent variables (pters, ptera and physint_tp). To save space, we only show the coefficients of the variables of interest and their levels of significance. For comparison, the first three columns in panel A repeat the results of Table 5, columns (1) to (3), while the first three columns in panel B repeat the results of Table 5, columns (4) to (6). The other columns in panels A and $\mathrm{B}$ report the results for the specifications in which we use ptera or physint_tp as the dependent variable. As can be seen, our results are robust to using alternative human rights indicators. In particular, in all six specifications of panels A and B in which we include the interaction between U.S. allies * (2001-2006) and independent judicial review, the coefficient of the variable U.S. allies * (2001-2006) is positive and statistically significant. The size of the coefficients is always considerably larger than before. Depending on the specification, the probability of a U.S. ally country with no independent judicial review staying in the best human rights regime falls by $10.9,12.2,8.4,8.8,11.5$ or $11.2 \%$ points for each of the post-9/11 years. The coefficient for the interaction term between U.S. allies * (2001-2006) and independent judicial review is always negative and statistically significant in five out of six specifications. Hence, the effect of $9 / 11$ is significantly smaller in countries with independent judicial review. In fact, the net effect of $9 / 11$ in these countries is never statistically significant. This again suggests that independent judicial review fully mitigated the $9 / 11$ effect on human rights. The results for the subsamples are consistent with these findings. While the coefficient for U.S. allies * (2001-2006) is always positive and statistically significant in five out of six specifications for countries without independent judicial review, it is always considerably smaller and never statistically significant for countries with independent judicial review.

A possible concern with these results is that they could in principle be driven by either 
judicial independence or judicial review, rather than the combination of both. To explore this possibility, we reran the six full sample specifications in Table 6 , panels A and B (ijr $=0 \mid 1$ ), but adding a dummy for countries with judicial independence and without judicial review and interactions of this dummy with each of the variables U.S. allies, (2001-2006), and U.S. allies * (2001-2006). If our results are driven by judicial independence only, then the effect of $9 / 11$ should be smaller for all countries with independence, not just for the ones that also have judicial review. The results indicated that judicial independence only mitigates the adverse effect of $9 / 11$ if it is combined with judicial review. We repeated this exercise with a dummy for countries with review but without independence and found that judicial review only mitigates the effect of $9 / 11$ if it is combined with judicial independence. Hence, both judicial review and judicial independence are necessary conditions and our results are really driven by the combination of both. ${ }^{27}$

We now investigate the sensitivity of our results using a range of alternative indicators for both the review and the independence component of our independent judicial review measure. We first change the judicial review component by reclassifying Israel, New Zealand and the U.K. as having review, as their courts do review laws even though they have limited authority to invalidate. As a second robustness check, we reclassified the countries that ratified the European Convention on Human Rights (ECHR) as having judicial review, as review (based on the ECHR) may be established through ratification. In both cases, the results are comparable to the original results, although slightly less significant, suggesting that the original classification is probably most appropriate. We also experimented with our own time-varying measure of judicial review, instead of the measure based on Maddex (2007). In particular, we obtained information on judicial review from the historical constitutions ${ }^{28}$ for each country from 1946 to 2006 . Our results are strongly

\footnotetext{
${ }^{27}$ We also reran the specifications with separate dummies for countries with independence and full review and countries with independence and limited review. In most specifications, Wald tests on the coefficients of the interactions of these dummies with the variable U.S. allies * (2001-2006) did not reject the null of equal coefficients. This suggests that we can analyze the two groups as a common aggregate.

${ }^{28}$ Blaustein and Flanz (1973-2006), Peaslee (1950, 1956 and 1965) and various other sources. We moreover engage in background reading to capture cases where review was established outside the constitution.
} 
robust both in terms of the sign and size of the coefficients, as well as their significance.

We also tested the robustness of our results to replacing the judicial independence component by a new measure of independence. This measure is based on our own coding of the tenure of the highest court that exercises judicial review in historical constitutions and our update of the case law data by La Porta et al. (2004). It has a larger coverage than the original measure by La Porta et al. (2004). Moreover, while the original measure considers the tenure of both the Supreme Court and the Administrative Court, this new measure only considers the tenure of the court that exercises judicial review (which could be neither the Supreme nor the Administrative Court). We use this measure as an alternative for the La Porta et al. (2004) independence measure in both the regressions with the original judicial review measure and our own time-varying judicial review measure. In both cases, the results are comparable to the original results, although a little less significant.

\subsubsection{The Text of the Constitution}

While we found that independent judicial review matters, we have so far ignored the constitutional mandates of courts. If one views a constitution as a precommitment device enforced by the judiciary, then it matters which rights are in the constitution. Thus, the text of the constitution may determine whether a court will invalidate counter-terror laws. Particularly, constitutions with protective rights provisions make invalidation more likely. Yet, individual judges are also important. If judges exclusively rely on the text of the constitution in reaching decisions, text will be very important (Scalia (1997)). But if they interpret the words of the constitution broadly, so that they are morally just (Dworkin (1996)) or adapted to a broad underlying purpose (Breyer (2005)), the text of the constitution may prove less important. In the latter case, judges are often accused of (or praised for) "judicial activism", or placing undemocratic constraints on the political process.

To test the importance of the constitution, we identified six human rights that may have been compromised after 9/11: the right to life, the right not to be tortured, freedom from arbitrary arrests and detention, the right of access to a court when detained, the right to a timely trial and a composite of fair trial rights. We then documented for each 
country how many of these rights were present in the constitution in 2000 (Blaustein and Flanz 1973-2006). Using the median number of rights as a threshold, we divide the countries with independent judicial review in each of the subsamples of Table 6, panels $\mathrm{A}$ and $\mathrm{B}$, into countries with a large and countries with a small number of provisions in their constitution. Using these two groups, we rerun the specifications with $\mathrm{ijr}=1$ for each of the groups separately. We also rerun the specifications with an interaction term to test whether the effect of 9/11 significantly differs between those with a large and those with a small number of provisions. We find that for countries with independent judicial review, the post-9/11 increase in rights violations is lower in countries with a large number of constitutional rights provisions, but this effect is only significant in the pters and ptera specifications. Although these results should be interpreted with caution due to the fairly low number of observations, they seem to suggest that the text of the constitution matters for the degree to which independent courts protected rights after 9/11. We also tested whether the text of the constitution made a difference in countries without independent judicial review, but found no evidence that this is the case, casting doubt on the notion of 'popular constitutionalism', i.e. the idea that the people themselves, or their elected representatives, will enforce the constitution (Kramer (2004)). ${ }^{29}$

\subsection{Majoritarian Checks}

We now turn to majoritarian checks. As an indicator, we use the political constraints indicator "polconiii" from Henisz (2002), as it corresponds closely to our notion of majoritarian checks. In particular, this indicator captures whether a country has constitutionally effective upper and lower houses of parliament that are controlled by a party different from the other branches of government. It also takes into account whether the preferences within an opposition branch are homogeneous, as a more homogeneous branch constitutes

\footnotetext{
${ }^{29}$ For robustness, we repeated this exercise using a larger set of seventeen human rights with similar results. Since the European Convention on Human Rights (ECHR) may be an important supplement to European national constitutions, we also repeated this exercise using indicators in which ECHR provisions are added to the domestic provisions. However, we find no supplementary effect of the ECHR.
} 
a stronger veto power. Just as in the case of counter-majoritarian checks, we use a dummy variable, which takes a value of one for high levels of political constraints and zero for low levels. As a threshold, we use the median of the variable polconiii for the common sample of treatment observations in Tables 3 and 4. For the 353 treatment observations for which we have data on political constraints, the political constraints dummy is one in 176 cases and zero in 177 cases. Using this dummy variable, we estimate the same specifications as for counter-majoritarian checks in Table 6, panels A and B. The results are reported in Table 6 , panels $\mathrm{C}$ and D. ${ }^{30}$ As can be seen, we do not find any systematic difference between the human rights effects in countries with low levels of political constraints and countries with high levels of political constraints. ${ }^{31}$ Hence, after 9/11, majoritarian checks did not constrain governments in violating rights. This suggests that a majority of citizens was willing to trade liberty for more (perceived) security. To investigate the possibility that majoritarian checks only work in the absence of counter-majoritarian checks, we reran the specifications of Table 6 , panels $\mathrm{C}$ and $\mathrm{D}$, using only countries without independent judicial review. Again, we find no evidence that majoritarian checks matter. ${ }^{32}$

We next consider alternative constitutional characteristics that may prevent the executive from acting against majority will. First, countries with parliamentary systems (as opposed to presidential systems) may have seen fewer post-9/11 rights violations, as the legislative branch is more powerful and can sent the executive out of office. Second, countries with proportional (as opposed to majoritarian) electoral rules may also have suffered

\footnotetext{
${ }^{30}$ The numbers of total observations and treatment observations in the full samples of Table 5, panel C, are 3404 and 306, 2644 and 251, and 2953 and 288, respectively. For panel D, these numbers are 3406 and 299, 2644 and 250, and 2955 and 287, respectively.

${ }^{31}$ As a robustness check, we repeated this procedure using the variable "checks" from Keefer and Stasavage (2003), but again found no evidence that majoritarian checks matter.

${ }^{32}$ We have so far looked at counter-majoritarian and majoritarian checks separately. We also ran the specifications in Table 6 with both the independent judicial review dummy and the political constraints dummy (the correlation is 0.09). Our results are robust in terms of size and statistical significance. Hence, even when controlling for political constraints, independent judicial review effectively mitigates post-9/11 rights violations. At the same time, when controlling for independent judicial review, we still find no significant effect of political constraints.
} 
fewer violations, as multi-party coalition governments have to reach consensus and are therefore required to take minority interests into account. Using a range of alternative indicators from Persson and Tabellini (2003), the Database of Political Institutions (Beck et al. (2001)), and Golder (forthcoming), we did not find any evidence that the $9 / 11$ effect was smaller in countries with parliamentary systems or proportional electoral rules.

\section{Sensitivity, Endogeneity and Serial Correlation}

We performed several robustness checks for the specifications of Tables 3 to 6 . First, we reran the specifications with 1 lag (as is common in the empirical human rights literature) and 5 lags (the ones that enter statistically significant) of the dependent variable. Second, we experimented with the inclusion of additional control variables (trade openness, international war, region dummies and year dummies). In both cases, the estimation results were very similar to the results in Tables 3 to 6 .

\subsection{Endogeneity}

We have so far ignored the potential endogeneity of the explanatory variables. Below we address three sources of endogeneity: omitted variables, reverse causality and measurement error. We start with the adverse effect of $9 / 11$ on human rights. If the variable $t_{i} \cdot p_{t}$ in equation (1) is correlated with the error term $\varepsilon_{i, t}$, then our estimate of the true effect of $9 / 11(\delta)$ is biased. A possible reason for this correlation that is specific to differences-in-differences estimation, is the failure of the parallel-trend assumption. Differences-in-differences estimation can only be used when in the absence of $9 / 11$, U.S. ally countries would not have had a differential trend in human rights violations relative to other countries. Although the validity of this assumption cannot be tested, one can investigate its plausibility by using long time series of data from before 9/11 and comparing pre-9/11 trends (Duflo and Kremer (2005)). Following this approach, we rerun the specifications of Tables 3 and 4, columns (4) to (6), but instead of including the post-2000 dummy and its interaction with the U.S. ally variable, we now include separate dummy variables for each of the years in 
the sample, and interactions of these year dummies with the U.S. ally variable. ${ }^{33}$ Figure 2 graphs the coefficients of these interactions as a function of time for each of the six specifications. The coefficients for each year capture the difference between the average level of rights violations in U.S. ally countries and the average level in other countries, relative to the difference in 1992. Hence, if violations in U.S. ally countries had a differential trend prior to $9 / 11$, this should be reflected in the coefficients for the pre-2001 years. If, for example, violations had a relative upward trend in U.S. ally countries, then the lines in Figure 2, based on a regression of the pre-2001 coefficients on the variable year, should be upward sloping. If, on the other hand, violations had a relative downward trend, the lines should be downward sloping. As can be seen from Figure 2, we do not find systematic evidence of a differential pre-9/11 trend in U.S. ally countries. In fact, the slope of the regression line is positive in three of the six specifications and negative in the other three specifications. More importantly, the coefficient in the underlying regression is statistically insignificant in five out of the six specifications, while significant at 10 percent (but negative) for the specification of Table 3, column (5). These results are reassuring as they reinforce confidence in the assumption of parallel trends. ${ }^{34}$

But even in the absence of a differential pre-9/11 trend, our estimate of the effect of the post-9/11 terror threat may suffer from omitted variable bias due to other events that occurred around the same time. Two types of events seem particularly likely to be correlated with our treatment variables. The first is the incidence of domestic terrorist attacks in U.S. ally countries, such as the attacks in Madrid in 2004 and London in 2005. In section 3 , we already found that the effect of $9 / 11$ is equally strong once we control for such attacks. Hence, even though domestic terrorist attacks affect human rights, this does not bias the estimates of the $9 / 11$ effect. The second type of event is participation

\footnotetext{
${ }^{33}$ We exclude the median year of the pters and ptera samples (1992) as the reference year.

${ }^{34}$ We repeated this exercise for the smaller group of U.S. ally countries without independent judicial review, as we have found that the 9/11 effect is confined to these countries. Again, we do not find evidence of a differential trend. To allow for possible differential trends during the cold war, we also re-estimated the specifications of Tables 3 and 4 for post-1989 observations only. The results were robust and the coefficients gained in terms of size and statistical significance.
} 
in international wars. If participation in the wars in Afghanistan and/or Iraq has an effect on human rights at home, then the estimated effect of $9 / 11$ could be due to war participation rather than the adoption of domestic counter-terrorism measures. Since the wars in Afghanistan and Iraq started in the aftermath of 9/11, it is difficult to separate a possible effect of participation in these wars from an effect of the post-9/11 terror threat. However, if one can identify another time interval during which similar events occurred, it is possible to investigate the likelihood that these events drive the results. In the case of the wars in Afghanistan and Iraq, the first Gulf War in Iraq in 1990 and 1991 represents such a time interval. If war participation affects rights at home, one would expect to see an increase in rights violations in countries that deployed troops in Iraq during the first Gulf War. To investigate this possibility, we reran the specifications of Tables 3 and 4 but instead of the post-9/11 variables, we now include a dummy variable for troop deployment in Iraq in 1990 and/or 1991, a dummy variable for the period 1990-1991, and an interaction term of both dummies. The coefficient of the interaction term was never statistically significant, indicating that troop deployment in the first Gulf War did not affect human rights at home. It therefore seems unlikely that the estimated effect of the post-9/11 terror threat is explained by participation in the wars in Afghanistan and/or Iraq. ${ }^{35}$

To control for any time-invariant omitted variables, we also experimented with the fixed-effects ordered logit estimator developed by Ferrer-i-Carbonell and Frijters (2004). ${ }^{36}$ Our results in Tables 3 and 4, columns (4) to (6), are robust to the inclusion of country fixed effects. In particular, the coefficients of the interaction term of the U.S. allies indicator and the period specific effect (2001-2006) are always positive and are statistically significant

\footnotetext{
${ }^{35}$ The interaction of the dummy for troop deployment in Afghanistan and/or Iraq and the dummy for (2001-2006) may be correlated with other omitted variables that affect human rights. If governments that care little about human rights are more likely to join the war on terror, the coefficient of the interaction will be biased. However, the results for the specifications in which we use the pre-9/11 U.S. alliances, show that this problem is not likely to be important. In addition, although there were prior terror threats, an event of the magnitude of 9/11 was largely unexpected and can be viewed as an exogenous shock to the (perceived) threat of future terrorist attacks.

${ }^{36}$ We thank Ada Ferrer-i-Carbonell and Paul Frijters for generously sharing the codes.
} 
at 1 percent in four specifications, while significant at 5 and 10 percent in the other two specifications. Although our results are robust to including fixed effects, these fixed effects estimations are not our preferred specifications. This is due to the fact that the fixed-effects ordered logit estimation involves a collapse of the ordinal dependent variables into binary variables, which reduces the variation used in estimation.

In addition to omitted variable bias, endogeneity can also arise from reverse causality if the interaction of the U.S. allies variables and the (2001-2006) variable is itself depending on the level of human rights violations. However, it seems very unlikely that Al-Qaeda planned the 9/11 attacks in anticipation of domestic rights violations in U.S. ally countries. The same holds for the decision of countries to join NATO, EAPC or other alliances.

Finally, we consider possible biases due to measurement error in our human rights indicators. In particular, we investigate the possibility that in these ordinal indicators an identical increase in rights violations may show up disproportionately among countries that start with a low score (or strong rights record). If our indicators are only able to capture rights violations in countries with strong rights records, and most U.S. allies have stronger rights records than non-allies, our results may be biased. In order to investigate this possibility, we add an interaction term between the variables (2001-2006) and Human rights violations $_{t-1}$ to the specifications of Tables 3 and 4 , columns (4) to (6). The coefficient of this interaction term reflects how the general post-2000 change in rights violations (i.e. the change that is common to the treatment and control groups) depends on the level of violations in the previous year. If there is a general post-2000 effect that is disproportionately reflected in the rights scores of countries with a low level of violations in the previous year, the coefficient of the interaction term should be negative and statistically significant. The results of this exercise show that the coefficient of the interaction term is statistically insignificant and close to zero in all six specifications. This indicates that any general post-2000 effect is not significantly smaller for countries with a higher initial level of violations. In addition, adding the interaction term does not change our finding that the post-9/11 terror threat has led to an increase in rights violations in U.S. ally countries, as the coefficients of the variable U.S. allies * (2001-2006) hardly change and 
remain statistically significant in all six specifications. These results cast strong doubts on the hypothesis that our findings are explained by measurement error. ${ }^{37}$

We next address the potential endogeneity of independent judicial review. We first consider omitted variable bias. In particular, if independent judicial review is correlated with omitted variables that affect human rights, we may wrongfully attribute their effect to independent judicial review. One possibility is that countries may have changed their constitutional arrangements on the judiciary after $9 / 11$ in order to be able to effectively fight terrorism. If countries with stricter counter-terrorism policies and more rights violations after $9 / 11$ have at the same time amended their constitutions to reduce the power of courts, then this could explain our results. La Porta et al. (2004) claim that constitutional provisions on judicial review and judicial independence have been stable over time, thus suggesting that these provisions are predetermined with respect to post- $9 / 11$ policies. In order to investigate whether this is the case, we collect historical data on judicial reform. In particular, we analyze all constitutions for each country from 1946 to 2006 and code a range of eighteen provisions ${ }^{38}$ on the judiciary. We then for each country identify episodes

\footnotetext{
${ }^{37}$ For sensitivity, we also performed this exercise with an interaction between "2001-2006" and a dummy that takes a value of one if a country was in the best possible rights regime in the previous year, and zero otherwise. We also added the dummy by itself. Consistent with the first exercise, we find no evidence that the general post-2000 change in violations is significantly larger for countries with the lowest possible initial level of violations. Also, adding the interaction again does not change our finding that 9/11 led to an increase in rights violations. Finally, we considered the possibility that the $9 / 11$ effect itself depends on the initial level of rights violations. Dreher, Gassebner and Siemers (forthcoming) find that the effect of domestic terror on human rights strongly depends on the level of rights. Using the same approach as before, we did not find any evidence that the $9 / 11$ effect is non-linear.

${ }^{38} 1$ : whether there is de facto judicial review, 2: whether there is judicial review in the constitution, 3 : which court exercises review, 4: whether this is a specialized or a general court, 5: whether review takes place before adoption of a law, 6: whether review takes place after adoption of a law, 7: whether review can be initiated by state actors, 8: whether review can be initiated by individual citizens, 9: whether the constitution allows for the review of legislation, 10: whether the constitution allows for the review of regulation, 11: whether the constitution allows for the review of international treaties, 12: whether review creates inapplicability of an unconstitutional law only in the case before the court or in general, 13: the tenure of judges, 14: whether elected representatives rather than courts exercise review, 15: whether a
} 
of judicial reform as years in which at least one of the eighteen judicial provisions changed. We look at all these detailed arrangements rather than judicial review alone because we feel that if a government would want to curtail the power of the judicial branch, it would probably do so in indirect ways. Using this information, we then rerun the specifications in Tables 6, panels A and B, without the countries that reformed their judiciary after $2000 .{ }^{39}$ The coefficients are very similar to the coefficients in the original specifications both in terms of size and significance, suggesting that our results are not driven by judicial reforms after $9 / 11$. To more generally test whether independent judicial review is predetermined, we also performed this exercise excluding all countries that reformed their judiciary since 1978 (the beginning of our sample period)..$^{40}$ Although this substantially reduces our sample size, the results are still comparable to the original specifications. If anything, the size and significance of the coefficients increases in this reduced sample, suggesting that if there is any bias, it is likely to lead to an underestimation of the effects of $9 / 11$ and independent judicial review. We thus conclude that, while a substantial number of countries reformed their judicial branch, this is unlikely to have biased our results.

Although these results are reassuring, they do not take away all concerns over potential omitted variable bias. Even if independent judicial review is sufficiently predetermined with respect to $9 / 11$, it may be correlated with other institutional characteristics that affect human rights. To address this concern, we collected a wide range of thirteen institutional indicators, capturing general institutional quality, democracy and autocracy, law and order, checks and balances, voice and accountability, political stability, government effectiveness, regulatory quality, rule of law and control of corruption. ${ }^{41}$ Since many of these quasi judicial body with both judges and politicians exercises review, 16: whether only regional legislation can be reviewed by the court, 17: whether only international treaties can be reviewed by the court, 18 : whether only regulations can be reviewed by the court. This coding was based on Blaustein and Flanz (1973-2006), Peaslee (1950, 1956 and 1965) and various other sources. We moreover engage in background reading to document cases where review was established outside the constitution.

${ }^{39} 3$ countries in the sample reformed their judiciary: Chile, Indonesia and Iraq (all non-U.S. allies).

${ }^{40} 33$ countries in the sample reformed their judiciary since 1978 (13 U.S. allies). We also excluded Germany and Zimbabwe due to missing data on judicial reform for some of the years since 1978.

${ }^{41}$ We use the International Country Risk Guide (ICRG) 'composite risk' and 'law \& order' ratings 
indicators have ordinal scales, we constructed thirteen dummy variables that take a value of one for high institutional quality and zero for low institutional quality. As thresholds, we use the medians for the common sample of treatment observations in Tables 3 and 4 . Independent judicial review is not strongly correlated with other institutional characteristics. The correlations range from -0.09 for law \& order to 0.13 for checks and balances, while for most of the dummies the correlation is close to zero. To investigate whether our results are explained by institutions other than independent judicial review, we first replaced independent judicial review in Table 6, panels A and B, by the institutional dummy variables and reran the specifications for each of the thirteen dummies separately. We do not find any evidence that institutions (other than independent judicial review) mitigate the adverse effect of $9 / 11$ on human rights. We then repeated this exercise but now including independent judicial review alongside each of the institutional dummy variables. Controlling for other institutional characteristics does not substantially change our results for independent judicial review. The coefficients of its interactions with the variable U.S. allies * (2001-2006) are always negative, while the size of the coefficients is similar to the size of the coefficients in Table 6 . The statistical significance is also relatively robust. We believe these results indicate that it is independent judicial review that is important and not any other institutional characteristic. ${ }^{42}$

We consider two further potential sources of omitted variable bias: legal origin and culture. In recent years, scholars have advanced the 'legal origin' thesis, or the idea that common law systems perform better than civil law systems in protecting investor rights (La from the PRS Group (1979-2007), executive constraints ('exconst'), democracy ('democ'), autocracy ('autoc') and a combined measure of democracy and autocracy ('polity2') from PolityIV, checks and balances ('checks') from the Database of Political Institutions (Beck et al. (2001)), and the six World Bank governance indicators from Kaufmann, Kraay and Mastruzzi (2008), i.e. voice and accountability, political stability, government effectiveness, regulatory quality, rule of law and control of corruption.

${ }^{42}$ For sensitivity, we experimented with the joint inclusion of all six dummy variables based on the World Bank governance indicators from Kaufmann, Kraay and Mastruzzi (2008), rather than one by one. Controlling for all six dimensions of governance again did not change our finding that independent judicial review mitigates the adverse effect of $9 / 11$ on human rights. 
Porta et al. (1997)), protecting property rights (La Porta et al. (1999)) and ensuring judicial independence (La Porta et al. (2004), Berkowitz and Clay (2006)). Since case law is a component of our independent judicial review indicator, and case law is a defining feature of common law, legal origin is correlated with independent judicial review. Some scholars moreover find that legal origin affects human rights (Dreher, Gassebner and Siemers, (forthcoming)). To test for omitted variable bias, we repeat the exercise for institutional quality described above, using a dummy for English common law from La Porta et al. (1999). ${ }^{43}$ We find that legal origin did not mitigate the effect of $9 / 11$ on rights, while our findings for independent judicial review are robust to the inclusion of legal origin.

With respect to culture, it is possible that countries with a strong 'culture of human rights' have adopted protective constitutions and have established strong judicial review, while also refraining from counter-terrorism that comes at the expense of rights. It is hard to quantify legal culture, or human rights culture in particular. Nevertheless, the measures developed by Hofstede (2001), based on a values survey among citizens, capture dimensions of a human rights culture. First, the uncertainty avoidance index may capture the extent to which societies are willing to sacrifice rights to reduce the risk of terror (with more uncertainty avoidance leading to more rights violations). Second, the individualism index may capture the value societies attach to individual liberty rights (with individualism leading to fewer rights violations). Finally, the unequal power distribution index may capture the extent to which societies accept the rights violations of less powerful groups in society (with more unequal power distribution leading to more rights violations). We find that these measures are correlated with independent judicial review in the expected manner. But when repeating the exercise described above with dummy variables for these cultural dimensions, we find that culture neither mitigates the adverse effect of 9/11 on human rights, nor removes the effect we find for independent judicial review.

Finally, our results for independent judicial review are not likely to be driven by reverse causality as we have shown above that excluding the three countries that reformed their judiciary after 2000 does not affect our results.

\footnotetext{
${ }^{43}$ The correlation between independent judicial review and English common law is 0.49.
} 


\subsection{Serial Correlation}

Another problem with differences-in-differences estimation that has received a lot of attention is the potential bias in the standard errors of the estimated coefficients due to serial correlation in the error terms. Bertrand, Duflo and Mullainathan (2004) argue that this bias is likely to be particularly large in differences-in-differences estimation, as it typically uses long time series, a positively serially correlated dependent variable and a treatment variable that is by construction also positively serially correlated. They randomly generate placebo laws in state-level data on female wages and, consistent with their argument, find that conventional OLS standard errors are severely downwards biased and lead to a significant effect at the 5 percent level for up to 45 percent of the placebo interventions. They assess various techniques to reduce the bias and find among other things that the inclusion of lagged dependent variables, as in our analysis, does not solve the serial correlation problem. However, computing standard errors that are heteroskedasticity- and serial correlation-robust (White (1984), Arellano (1987)), as we do in all our estimations, performs well in large samples with at least 50 clusters (Bertrand, Duflo and Mullainathan (2004), Kézdi (2004)). Given that the number of clusters (countries) in our analysis ${ }^{44}$ far exceeds 50, any bias in the standard errors of the coefficients is likely to be negligible.

To assess the validity of this claim, we randomly generated placebo treatments in our baseline estimation sample of Table 3, column (4). We first randomly selected 100 sixyear periods in our sample period 1978-2006 and constructed a dummy variable for each period. We then randomly selected 100 groups of 51 placebo "treatment" countries out of the 147 countries in the sample and constructed a dummy variable for each group. ${ }^{45} \mathrm{We}$ then reran the specification in Table 3, column (4), but instead of the variables U.S. allies, (2001-2006), and U.S. allies * (2001-2006), we include the first random group dummy, the first random period dummy, and an interaction between the two dummies. The coefficient of the latter interaction term captures the effect of the placebo treatment. We repeat this

\footnotetext{
${ }^{44}$ The specifications of Tables 3 and 4, columns (4) to (6), include around 147 countries.

${ }^{45}$ Our choice of six-year periods and groups of 51 countries was based on the length of the post-9/11 period in our estimations and the number of actual treatment countries in the sample, respectively.
} 
estimation procedure for the other 99 random period and group dummies. This results in the estimation of the effects of a total of 100 placebo treatments. As explained by Bertrand, Duflo and Mullainathan (2004), this is analogous to asking "If [100] researchers analyzed the effects of various [treatments in our estimation sample], what fraction would find a significant effect even when the [treatments] have no effect?" If the heteroskedasticity- and serial correlation-robust standard errors in our estimations are unbiased and we evaluate the significance of the coefficients at the 5 percent level, we would expect to find a significant effect of the placebo treatment in around 5 of the 100 regressions. Similarly, if we evaluate at the 1 or 10 percent levels, we would expect to find a significant effect in around 1 or 10 of the 100 regressions, respectively. Our results show that the effect of the placebo treatment is significant at 10 percent in 10 out of the 100 regressions, significant at 5 percent in 6 out of the 100 regressions, and significant at 1 percent in 2 out of the 100 regressions. Hence, the numbers of significant coefficients are very close to the expected levels for unbiased standard errors. This is reassuring as it supports our claim that the standard errors in our estimations are not biased.

\section{Conclusions}

9/11, security, human rights and the institutional system have featured prominently in the work of lawyers, political theorists and philosophers over the last couple of years. Yet, there has been surprisingly little empirical analysis. This paper is the first to provide crosscountry evidence on the effects of 9/11 on rights as well as how this plays out under different institutional conditions. As one may perhaps have suspected from recent newspaper headlines, human rights have significantly deteriorated in the West after 9/11. These rights violations are mainly driven by incidents of torture and political imprisonment. They were strongest in the first post-9/11 years and decreased again thereafter. In countries with independent judicial review, courts prevented these rights violations. By contrast, veto players in the legislative branch did not do so. Constitutional precommitments to rights were important in the hands of the judiciary, but had no effect by themselves. 
But some important questions remain. Our results suggest that rights violations decreased again after 2004. As a result, we tentatively conclude that there has been no 'ratchet effect', or slippery slope from increased security to repression. But we are aware that counter-terror laws in many countries remain on the books and could be used at any time. When longer time series become available, it may be worth exploring the long-term impact of $9 / 11$ on human rights. Moreover, while courts have protected rights in the aftermath of $9 / 11$, the implications for security are unclear. If one believes that there is a direct tradeoff between rights and security (Posner and Vermeule (2008)), courts may have jeopardized the security of their citizens. But so far, no empirical evidence has been provided that such a tradeoff actually exists. If anything, empirical evidence suggests that the war on terror has not decreased the probability of terror attacks (Enders and Sandler (2005)). Empirical research on the security liberty tradeoff would help us to explore the normative implications of our findings. 


\section{References}

[1] Ackerman, Bruce. 2004. "The Emergency Constitution." Yale Law Journal 113: 10291092.

[2] Arellano, Manuel. 1987. "Computing Robust Standard Errors for Within-Groups Estimators." Oxford Bulletin of Economics and Statistics 49: 431-434.

[3] Australian Human Rights Commission. 2008. A Human Rights Guide to Australia's Counter-terrorism Laws.

[4] Barak, Aharon. 2002. "A Judge on Judging: The Role of a Supreme Court in a Constitutional Democracy." Harvard Law Review 116: 16-162.

[5] Barro, Robert J., and Rachel M. McCleary. 2005. "Which Countries Have State Religions?" Quarterly Journal of Economics 120: 1331-1370.

[6] Beck, Thorsten, Clarke, George, Groff, Keefer, Philip, and Patrick Walsh. 2001. "New Tools in Comparative Political Economy: The Database of Political Institutions." World Bank Economic Review 15:165-176.

[7] Benvenisti, Eyal. 2008. "Reclaiming Democracy: The Strategic Uses of Foreign and International Law by National Courts." American Journal of International Law 112: 241-274.

[8] Berkowitz, Daniel, and Karen Clay. 2006. "The Effect of Judicial Independence on Courts: Evidence from the American States." Journal of Legal Studies 35: 399-440.

[9] Bertrand, Marianne, Duflo, Esther, and Sendhil Mullainathan. 2004. "How Much Should We Trust Differences-in-Differences Estimates?" Quarterly Journal of Economics 119: 249-275.

[10] Bozolli, Carlos, and Cathérine Müller. 2008. "Perceptions and Attitudes to Terrorist Shocks: Evidence from the UK." unpublished manuscript.

[11] Blaustein, Albert P., and Gisbert H. Flanz. 1973-2006. Constitutions of the Countries of the World. New York, NY: Oceanalaw Publications.

[12] Breyer, Steven. 2005. Active Liberty: Interpreting our Democratic Constitution. New York, NY: Knopf.

[13] Cicero, M. Tullius. 52 BC. Pro Milone. in Perseus Digital Library Project, edited by Gregory R. Crane.

[14] Cingranelli, David L., and David L. Richards. 2008. The Cingranelli-Richards Human Rights Dataset Version 2008.03.12.

[15] Cole, David. 2003. "Their Liberties, Our Security: Democracy and Double Standards." International Journal of Legal Information 31: 290-311.

[16] Cole, David, and James X. Dempsey. 2006. Terrorism and the Constitution: Sacrificing Civil Liberties in the Name of National Security. New York: W.W. Norton \& Company.

[17] Davis, Darren, and Brian D. Silver. 2004. "Civil Liberty vs. Security: Public Opinion in the Context of the Terrorist Attacks on America." American Journal of Political Science 48: 28-46. 
[18] Dreher, Axel, Gassebner, Martin, and Lars H. R. Siemers. Forthcoming. "Does Terror Threaten Human Rights? Evidence from Panel Data." Journal of Law and Economics.

[19] Duflo, Esther, and Michael Kremer. 2005. "Use of Randomization in the Evaluation of Development Effectiveness." 205-232 in Evaluating Development Effectiveness, edited by George Pitman, Osvaldo Feinstein and Gregory Ingram. New Brunswick, NJ: Transaction Publishers.

[20] Dworkin, Ronald. 1977. Taking Rights Seriously. Cambridge, MA: Harvard University Press.

[21] Dworkin, Ronald. 1996. Freedom's Law: the Moral Reading of the American Constitution. Cambridge, MA: Harvard University Press.

[22] Dworkin, Ronald. 2003. "Terror and the Attack on Civil Liberties." the New York Review of Books 50: 37-41.

[23] Elster, Jon. 1979. Ulysses and the Sirens. Cambridge: Cambridge University Press.

[24] Elster, Jon. 1993. "Majority Rule and Individual Rights." 175-216 in the Oxford Amnesty Lectures. New York, NY: Basic Books.

[25] Enders, Walter, and Todd Sandler. 2005. "After 9/11: Is it All Different Now?" Journal of Conflict Resolution 49: 259-277.

[26] Epstein, Lee, Ho, Daniel E., King, Gary, and Jeffrey Segal. 2005. "The Supreme Court During Crisis: How War Affects Only Non-War Cases." New York University Law Review 80: 1-116.

[27] Ferrer-i-Carbonell, Ada, and Paul Frijters. 2004. "How Important is Methodology for the Estimates of the Determinants of Happiness?" Economic Journal 114: 641-659.

[28] Gibler, Douglas M., and Meredith Sarkees. 2004. "Measuring Alliances: The Correlates of War Formal Interstate Alliance Dataset, 1816-2000." Journal of Peace Research 41: $211-222$.

[29] Gibney, Mark, Cornet, Linda, and Reed Wood. 2008. Political Terror Scale 1976-2006.

[30] Gleditsch, Kristian Skrede. 2004. "A Revised List of Wars Between and Within Independent States, 1816-2002." International Interactions 30: 231-262.

[31] Golder, Matt. 2005. "Democratic Electoral Systems Around the World 1946-2000." Electoral Studies 24: 103-121.

[32] Hamilton, Alexander, and James Madison. 1788. "The Structure of the Government Must Furnish the Proper Checks and Balances Between the Different Departments." The Federalist Papers 51.

[33] Hafner Burton, Emilie M., and Kiyoteru Tsutsui. 2005. "Human Rights Practices in a Globalizing World: The Paradox of Empty Promises." American Journal of Sociology 110: $1373-1411$.

[34] Hafner Burton, Emilie M, and Kiyoteru Tsutsui. 2007. "Justice Lost! The Failure of International Human Rights to Matter Where Needed Most." Journal of Peace Research 44: 407-425.

[35] Henisz, Witold J. 2002. "The Institutional Environment for Infrastructure Investment." Industrial and Corporate Change 11: 355-389. 
[36] Hofstede, Geert. 2001. Culture's Consequences, Comparing Values, Behaviors, Institutions, and Organizations Across Nations. Thousand Oaks, CA: Sage Publications.

[37] Holmes, Stephen. 1988. "Precommitment and the Paradox of Democracy." 195-240 in Constitutionalism and Democracy, edited by Jon Elster and Rune Slagstad. Cambridge: Cambridge University Press.

[38] Ignatieff, Michael. 2004. The Lesser Evil: Political Ethics in an Age of Terror. Princeton, NJ: Princeton University Press.

[39] Issacharoff, Sammuel, and Richard H. Pildes. 2004. "Between Civil Libertarianism and Executive Unilateralism: An Institutional Process Approach to Rights During Wartime." Theoretical Inquiries in Law 5: 1-45.

[40] Kaufman, Daniel, Kraay, Aart, and Massimo Mastruzzi. 2008. "Governance Matters VII: Aggregate and Individual Governance Indicators, 1996-2007." World Bank Policy Research Working Paper No. 4654.

[41] Keefer, Philip, and David Stasavage. 2003. "The Limits of Delegation: Veto Players, Central Bank Independence and the Credibility of Monetary Policy." American Political Science Review 47: 389-402.

[42] Kézdi, Gabor. 2004. "Robust Standard Error Estimation in Fixed-Effects Panel Models." Hungarian Statistical Review 9: 95-116.

[43] Koh, Harold Hongju. 2002. "The Spirit of the Laws." Harvard International Law Journal 43: 23-40.

[44] Kramer, Larry D. 2004. The People Themselves: Popular Constitutionalism and Judicial Review. Oxford: Oxford University Press.

[45] LaFree, Gary, and Laura Dugan. 2008. Global Terrorism Database I and II.

[46] La Porta, Rafael, López-de-Silanes, Florencio, Shleifer, Andrei, and Robert W. Vishny. 1997. "Legal Determinants of External Finance." Journal of Finance 53: 1131-1150.

[47] La Porta, Rafael, López-de-Silanes, Florencio, Shleifer, Andrei, and Robert W. Vishny. 1999. "The Quality of Government." Journal of Law, Economics and Organization 15: $222-279$.

[48] La Porta, Rafael, López-de-Silanes, Florencio, Pop-Eleches, Cristian, and Andrei Shleifer. 2004. "Judicial Checks and Balances." Journal of Political Economy 112: 445-470.

[49] Levinson, Sanford. 2002. "Precommitment and Postcommitment: The Ban on Torture in the Wake of September 11." Texas Law Review 81: 2013-2054.

[50] Levinson, Daryl J., and Richard H. Pildes. 2006. "The Separation of Parties, not Powers." Harvard Law Review 119: 2311-2348.

[51] Library of Congress. 2002. Legislation related to the Attack of September 11, 2001.

[52] Maddala, G.S., and Shaowen Wu. 1999. "A Comparative Study of Unit Root Tests with Panel Data and a New Simple Test." Oxford Bulletin of Economics and Statistics 61: 631-652.

[53] Maddex, Robert L. 2007. Constitutions of the World. Washington: Congressional Quarterly Press. 
[54] Madison, James. 1787. "These Departments Should Not Be So Far Separated as to Have No Constitutional Control Over Each Other." The Federalist Papers 48.

[55] Montesquieu, Charles. 1748. The Spirit of the Laws, vol. 1.

[56] Peaslee, Amos J. 1950. Constitutions of Nations. Concord, NH: The Rumford Press.

[57] Peaslee, Amos J. 1956 and 1965. Constitutions of Nations. The Netherlands: Martinus Nijhoff.

[58] Persson, Torsten, and Guido E. Tabellini. 2003. The Economic Effects of Constitutions. Cambridge, MA: MIT Press.

[59] Poe, Steven C., and Neil Tate. 1994. "Repression of Human Rights to Personal Integrity in the 1980s: A Global Analysis." American Political Science Review 87: 85372 .

[60] Posner, Richard A. 2007. Not a Suicide Pact: the Constitution in a Time of National Emergency. New York, NY: Oxford University Press.

[61] Posner, Eric A., and Adrian Vermeule. 2008. Terror in the Balance: Security, Liberty and the Courts. Oxford: Oxford University Press.

[62] PRS Group. 1979-2007. The International Country Risk Guide (ICRG) rating.

[63] Rehnquist, William H.. 1998. All the Laws But One: Civil Liberties in Wartime. New York, NY: Random House.

[64] Roach, Kent. 2003. September 11: Consequences for Canada. Montreal: McGillQueen's Press.

[65] Scalia, Antonin. 1997. A Matter of Interpretation. Princeton, NJ: Princeton University Press.

[66] Schauer, Frederick. 2008. Incentives to Constitutional Compliance. Unpublished Manuscript.

[67] Scheppele, Kim Lane. 2004. "Other People's PATRIOT Acts: Europe's Response to September 11." Loyola Law Review 50: 89-148.

[68] Sunstein, Cass R. 2004. "Fear and Liberty." Social Research 71: 967-996.

[69] Stone, Geoffrey R. 2004. Perilous Times. New York, NY: W.W. Norton \& Company.

[70] Tsebelis, Georg. 2002. Veto Players: How Political Institutions Work. Princeton, NJ: Princeton University Press.

[71] Verbeek, Marno. 2000. A Guide to Modern Econometrics. Chichester: John Wiley \& Sons.

[72] Waldron, Jeremy. 1999. Law and Disagreement. New York, NY: Oxford University Press.

[73] White, Halbert. 1984. Asymptotic Theory for Econometricians. San Diego, CA: Academic Press.

[74] Yoo, John. 2005. The Powers of War and Peace: The Constitution and Foreign Affairs After 9/11. Chicago, IL: University of Chicago Press. 
Table 1: Summary statistics

\begin{tabular}{lccccc}
\hline \hline & Obs. & Mean & St. Dev. & Min. & Max. \\
\hline 1: pters & 3481 & 2.39 & 1.10 & 1 & 5 \\
2: ptera & 2960 & 2.70 & 1.05 & 1 & 5 \\
3: physint & 3199 & 3.12 & 2.25 & 0 & 8 \\
4: troops Afghanistan and Iraq (dummy) & 3581 & 0.17 & 0.37 & 0 & 1 \\
5: troops Afghanistan or Iraq (dummy) & 3581 & 0.33 & 0.47 & 0 & 1 \\
6: Nato (dummy) & 3583 & 0.12 & 0.33 & 0 & 1 \\
7: Nato Plus (dummy) & 3583 & 0.32 & 0.47 & 0 & 1 \\
8: (2001-2006) (dummy) & 3583 & 0.24 & 0.43 & 0 & 1 \\
9: GDP per capita (log) & 3583 & 7.46 & 1.58 & 4.69 & 10.72 \\
10: GDP per capita growth & 3583 & 0.02 & 0.05 & -0.63 & 0.64 \\
11: democracy & 3583 & 4.75 & 4.17 & 0 & 10 \\
12: population (log) & 3583 & 16.06 & 1.55 & 12.34 & 20.99 \\
13: civil war (dummy) & 3583 & 0.07 & 0.26 & 0 & 1 \\
14: independent judicial review (ijr) (dummy) & 1751 & 0.45 & 0.50 & 0 & 1 \\
15: political constraints (pc) (dummy) & 3570 & 0.31 & 0.46 & 0 & 1 \\
16: trade openness (log trade as \% of GDP) & 3437 & 4.16 & 0.55 & 1.84 & 6.16 \\
17: international war (dummy) & 3583 & 0.01 & 0.11 & 0 & 1 \\
\hline \hline
\end{tabular}

Sources: 1\&2: Gibney, Cornet and Wood (2008). 3: Cingranelli and Richards (2008). 4\&5: U.S. Central Military Command, CRS Report for Congress "Iraq: Foreign Contributions to Stabilization and Reconstruction (2007)", fact sheets by the U.S. Department of Defense and Nato and various web sites. 6\&7: Gibler and Sarkees (2004), Nato and U.S. Code title 22, s. 2321k. 9\&10: World Development Indicators (WDI). 11: Polity IV (data for 2005 and 2006 were missing so we used 2004 scores for these years). 12: WDI. 13: Gleditsch (2004) (data for 2006 were missing so we used the 2005 values for this year). 14: La Porta et al. (2004). 15: Henisz (2002) (data for 2005 and 2006 were missing so we used 2004 scores for these years). 16: WDI. 17: Gleditsch (2004) (data for 2006 were missing so we used the 2005 values for this year).

Explanation ordinal scale pters and ptera: 1) Countries under secure rule of law, people not imprisoned for their view, torture rare or exceptional. Political murders extremely rare. 2) Limited amount of imprisonment for nonviolent political activity. However, few persons affected, torture and beatings exceptional. Political murder rare. 3) Extensive political imprisonment, or recent history of such imprisonment. Execution or other political murders and brutality may be common. Unlimited detention, with or without a trial, for political views accepted. 4) Civil and political rights violations have expanded to large numbers of population. Murders, disappearances, and torture common part of life. In spite of its generality, on this level terror affects those who interest themselves in politics or ideas. 5) Terror has expanded to whole population. leaders of these societies place no limits on means or thoroughness with which they pursue personal or ideological goals. 


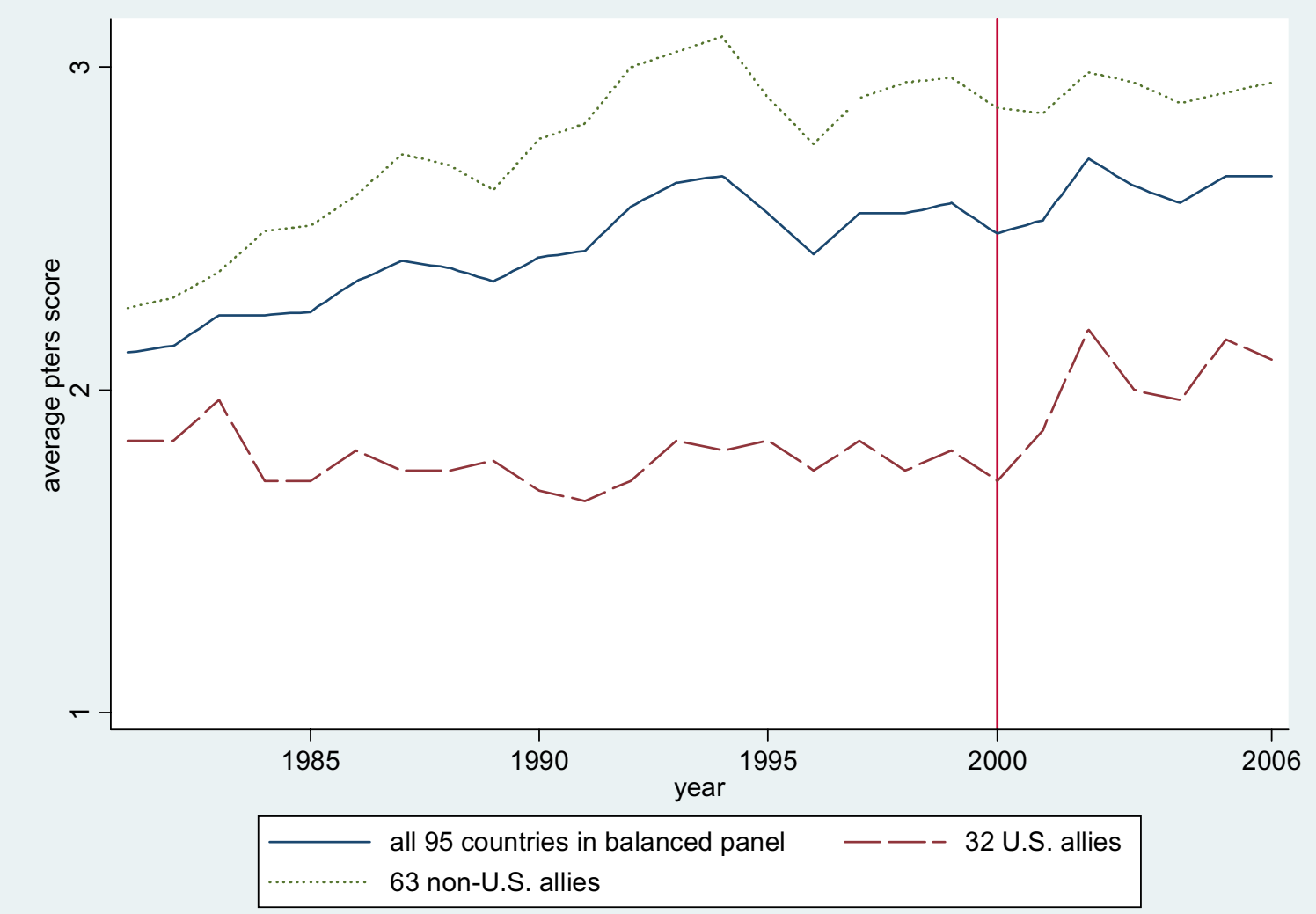

Figure 1: average levels of human rights violations (pters) in balanced panel 1981-2006 
Table 2: The United States and its pre- $9 / 11$ and post- $9 / 11$ allies

\begin{tabular}{|c|c|c|c|}
\hline \multicolumn{2}{|c|}{ Pre-9/11 } & \multicolumn{2}{|c|}{ Post-9/11 } \\
\hline Czech Republic & Czech Republic & Czech Republic & Czech Republic \\
\hline Denmark & Denmark & Denmark & Denmark \\
\hline Hungary & Hungary & Hungary & Hungary \\
\hline Iceland* & Iceland* & Iceland* & Iceland* \\
\hline Italy & Italy & Italy & Italy \\
\hline Netherlands & Netherlands & Netherlands & Netherlands \\
\hline Norway & Norway & Norway & Norway \\
\hline Poland & Poland & Poland & Poland \\
\hline Portugal & Portugal & Portugal & Portugal \\
\hline Spain & Spain & Spain & Spain \\
\hline United Kingdom & United Kingdom & United Kingdom & United Kingdom \\
\hline United States & United States & United States & United States \\
\hline Belgium & Belgium & Albania & Albania \\
\hline Canada & Canada $^{3}$ & Australia & Australia \\
\hline France & France & Azerbaijan & Azerbaijan \\
\hline Germany & Germany & Bulgaria & Bulgaria \\
\hline Greece & Greece & Estonia & Estonia \\
\hline Luxembourg* & Luxembourg* & Korea, Rep & Korea, Rep \\
\hline Turkey & Turkey & Latvia & Latvia \\
\hline & Albania $^{2}$ & Lithuania & Lithuania \\
\hline & Argentina $^{1}$ & Macedonia, FYR & Macedonia, FYR \\
\hline & Armenia $^{2}$ & Mongolia & Mongolia \\
\hline & Australia ${ }^{1,3}$ & New Zealand & New Zealand \\
\hline & Austria $^{2}$ & Romania & Romania \\
\hline & Azerbaijan $^{2}$ & Singapore & Singapore \\
\hline & Belarus $^{2}$ & Slovak Republic & Slovak Republic \\
\hline & Bulgaria $^{2}$ & Thailand & Thailand \\
\hline & Croatia $^{2}$ & & Armenia $^{I}$ \\
\hline & Egypt $^{1}$ & & Austria $^{A}$ \\
\hline & Estonia $^{2}$ & & Belgium $^{A}$ \\
\hline & Finland $^{2}$ & & Bosnia and Herz. ${ }^{I, *}$ \\
\hline & Georgia $^{2}$ & & Canada $^{A}$ \\
\hline & Ireland $^{2}$ & & Croatia $^{A}$ \\
\hline & Israel $^{1}$ & & Dominican Republic ${ }^{I}$ \\
\hline & Japan ${ }^{1,3}$ & & El Salvador ${ }^{I}$ \\
\hline & Jordan $^{1}$ & & Fiji \\
\hline & Kazakhstan $^{2}$ & & Finland $^{A}$ \\
\hline & Korea, Rep. ${ }^{1,3}$ & & France $^{A}$ \\
\hline & Kyrgyz Republic ${ }^{2}$ & & Georgia $^{I}$ \\
\hline & Latvia $^{2}$ & & Germany $^{A}$ \\
\hline & Lithuania $^{2}$ & & Greece $^{A}$ \\
\hline & Macedonia, FYR ${ }^{2}$ & & Honduras ${ }^{I}$ \\
\hline & Moldova $^{2}$ & & Ireland ${ }^{A}$ \\
\hline & New Zealand ${ }^{1}$ & & $\operatorname{Japan}^{I}$ \\
\hline & Philippines ${ }^{3}$ & & $\operatorname{Jordan}^{A}$ \\
\hline & Romania $^{2}$ & & Kazakhstan $^{I}$ \\
\hline & Russian Federation ${ }^{2}$ & & $\operatorname{Luxembourg}^{A, *}$ \\
\hline & Slovak Republic ${ }^{2}$ & & Moldova $^{I}$ \\
\hline & Slovenia $^{2}$ & & Nicaragua $^{I}$ \\
\hline & Sweden $^{2}$ & & Philippines ${ }^{I}$ \\
\hline & Switzerland ${ }^{2}$ & & Slovenia ${ }^{A}$ \\
\hline & Turkmenistan $^{2}$ & & Sweden $^{A}$ \\
\hline & Ukraine $^{2}$ & & Switzerland ${ }^{A}$ \\
\hline & Uzbekistan $^{2}$ & & Tonga ${ }^{I, *}$ \\
\hline & & & Turkey $^{A}$ \\
\hline & & & Ukraine $^{I}$ \\
\hline
\end{tabular}

*: not in estimation sample. 1: major non-NATO U.S. ally in 2000. 2: non-NATO EAPC member in 2000. 3: bilateral U.S. ally in 2000. A: sent troops to Afghanistan. I: sent troops to Iraq. 
Table 3: The effect of the post-9/11 terror threat on human rights (post-9/11 U.S. allies)

\begin{tabular}{|c|c|c|c|c|c|c|}
\hline & \multicolumn{3}{|c|}{ troops Afghanistan and Iraq } & \multicolumn{3}{|c|}{ troops Afghanistan or Iraq } \\
\hline & $\begin{array}{l}\text { pters } \\
(1)\end{array}$ & $\begin{array}{l}\text { ptera } \\
(2)\end{array}$ & $\begin{array}{l}\text { physint } \\
(3)\end{array}$ & $\begin{array}{l}\text { pters } \\
(4)\end{array}$ & $\begin{array}{l}\text { ptera } \\
(5)\end{array}$ & $\begin{array}{l}\text { physint } \\
\text { (6) }\end{array}$ \\
\hline U.S. allies & $\begin{array}{l}-0.27^{* *} \\
(0.12)\end{array}$ & $\begin{array}{l}-0.29^{* *} \\
(0.12)\end{array}$ & $\begin{array}{l}-0.27^{* *} \\
(0.11)\end{array}$ & $\begin{array}{l}-0.26^{* * *} \\
(0.08)\end{array}$ & $\begin{array}{l}-0.28^{* * *} \\
(0.08)\end{array}$ & $\begin{array}{l}-0.29 * * * \\
(0.08)\end{array}$ \\
\hline$(2001-2006)$ & $\begin{array}{l}0.27^{* * *} \\
(0.05)\end{array}$ & $\begin{array}{l}0.05 \\
(0.04)\end{array}$ & $\begin{array}{l}0.08^{*} \\
(0.04)\end{array}$ & $\begin{array}{l}0.24^{* * *} \\
(0.05)\end{array}$ & $\begin{array}{l}0.04 \\
(0.05)\end{array}$ & $\begin{array}{l}0.04 \\
(0.04)\end{array}$ \\
\hline U.S. allies * (2001-2006) & $\begin{array}{l}0.27^{* *} \\
(0.11)\end{array}$ & $\begin{array}{l}0.33^{* *} \\
(0.15)\end{array}$ & $\begin{array}{l}0.25^{* *} \\
(0.10)\end{array}$ & $\begin{array}{l}0.21^{* *} \\
(0.08)\end{array}$ & $\begin{array}{l}0.20^{* *} \\
(0.10)\end{array}$ & $\begin{array}{l}0.23^{* * *} \\
(0.07)\end{array}$ \\
\hline$\Delta$ prob. $\left(y_{i, t}=0\right)$ & & & $-10.0^{* *}$ & & & $-9.0^{* * *}$ \\
\hline$\Delta$ prob. $\left(y_{i, t}=1\right)$ & $-7.9^{* * *}$ & $-12.1^{* *}$ & $5.1^{* *}$ & $-6.6^{* * *}$ & $-7.4^{* *}$ & $4.4^{* * *}$ \\
\hline$\Delta$ prob. $\left(y_{i, t}=2\right)$ & $7.7^{* * *}$ & $11.3^{* *}$ & $3.6^{* *}$ & $6.4^{* * *}$ & $6.9^{* *}$ & $3.3^{* * *}$ \\
\hline$\Delta$ prob. $\left(y_{i, t}=3\right)$ & $0.2^{* *}$ & $0.8^{* *}$ & $1.1^{* *}$ & $0.2^{* *}$ & $0.5^{* *}$ & $1.1^{* * *}$ \\
\hline$\Delta$ prob. $\left(y_{i, t}=4\right)$ & 0.0 & 0.0 & $0.2^{* *}$ & 0.0 & 0.0 & $0.1 * * *$ \\
\hline$\Delta$ prob. $\left(y_{i, t}=5\right)$ & 0.0 & 0.0 & $0.0^{*}$ & 0.0 & 0.0 & $0.0^{* *}$ \\
\hline$\Delta$ prob. $\left(y_{i, t}=6\right)$ & & & 0.0 & & & $0.0^{*}$ \\
\hline$\Delta$ prob. $\left(y_{i, t}=7\right)$ & & & 0.0 & & & 0.0 \\
\hline$\Delta$ prob. $\left(y_{i, t}=8\right)$ & & & 0.0 & & & 0.0 \\
\hline Human rights violations $_{t-1}$ & $\begin{array}{l}1.02^{* * *} \\
(0.05)\end{array}$ & $\begin{array}{l}0.87^{* * *} \\
(0.05)\end{array}$ & $\begin{array}{l}0.43^{* * *} \\
(0.02)\end{array}$ & $\begin{array}{l}1.02^{* * *} \\
(0.05)\end{array}$ & $\begin{array}{l}0.86^{* * *} \\
(0.05)\end{array}$ & $\begin{array}{l}0.43^{* * *} \\
(0.02)\end{array}$ \\
\hline Human rights violations $_{t-2}$ & $\begin{array}{l}0.54^{* * *} \\
(0.04)\end{array}$ & $\begin{array}{l}0.47^{* * *} \\
(0.03)\end{array}$ & $\begin{array}{l}0.22^{* * *} \\
(0.02)\end{array}$ & $\begin{array}{l}0.54^{* * *} \\
(0.04)\end{array}$ & $\begin{array}{l}0.47^{* * *} \\
(0.04)\end{array}$ & $\begin{array}{l}0.21^{* * *} \\
(0.02)\end{array}$ \\
\hline GDP per capita (log) & $\begin{array}{l}-0.11^{* * *} \\
(0.02)\end{array}$ & $\begin{array}{l}-0.06^{* * *} \\
(0.02)\end{array}$ & $\begin{array}{l}-0.12^{* * *} \\
(0.03)\end{array}$ & $\begin{array}{l}-0.10^{* * *} \\
(0.02)\end{array}$ & $\begin{array}{l}-0.05^{* *} \\
(0.02)\end{array}$ & $\begin{array}{l}-0.10^{* * *} \\
(0.03)\end{array}$ \\
\hline GDP per capita growth & $\begin{array}{l}-0.94^{*} \\
(0.49)\end{array}$ & $\begin{array}{l}-1.31^{* * *} \\
(0.50)\end{array}$ & $\begin{array}{l}-0.41 \\
(0.42)\end{array}$ & $\begin{array}{l}-0.93^{*} \\
(0.49)\end{array}$ & $\begin{array}{l}-1.28^{* * *} \\
(0.50)\end{array}$ & $\begin{array}{l}-0.40 \\
(0.41)\end{array}$ \\
\hline Democracy & $\begin{array}{l}-0.05^{* * *} \\
(0.01)\end{array}$ & $\begin{array}{l}-0.03^{* * *} \\
(0.01)\end{array}$ & $\begin{array}{l}-0.04^{* * *} \\
(0.01)\end{array}$ & $\begin{array}{l}-0.04^{* * *} \\
(0.01)\end{array}$ & $\begin{array}{l}-0.03^{* * *} \\
(0.01)\end{array}$ & $\begin{array}{l}-0.04^{* * *} \\
(0.01)\end{array}$ \\
\hline Population (log) & $\begin{array}{l}0.12^{* * *} \\
(0.02)\end{array}$ & $\begin{array}{l}0.09^{* * *} \\
(0.02)\end{array}$ & $\begin{array}{l}0.13^{* * *} \\
(0.02)\end{array}$ & $\begin{array}{l}0.12^{* * *} \\
(0.02)\end{array}$ & $\begin{array}{l}0.09^{* * *} \\
(0.02)\end{array}$ & $\begin{array}{l}0.13^{* * *} \\
(0.02)\end{array}$ \\
\hline Civil war & $\begin{array}{l}0.63^{* * *} \\
(0.12)\end{array}$ & $\begin{array}{l}0.55^{* * *} \\
(0.10)\end{array}$ & $\begin{array}{l}0.57^{* * *} \\
(0.08)\end{array}$ & $\begin{array}{l}0.66^{* * *} \\
(0.12)\end{array}$ & $\begin{array}{l}0.58^{* * *} \\
(0.10)\end{array}$ & $\begin{array}{l}0.60^{* * *} \\
(0.08)\end{array}$ \\
\hline Observations & 3416 & 2680 & 2966 & 3416 & 2680 & 2966 \\
\hline Treatment observations & 150 & 114 & 143 & 306 & 257 & 293 \\
\hline Pseudo R-squared & 0.48 & 0.36 & 0.31 & 0.48 & 0.36 & 0.31 \\
\hline
\end{tabular}

Notes: For each regressor we report the estimated coefficient from the ordered probit model and the robust standard error of the coefficient clustered by country. For the regressor "U.S. allies * (2001-2006)" we also report the change in the probability of each outcome (in \% points) if the regressor increases from 0 to $1 .{ }^{* * *},{ }^{* *}$, and ${ }^{*}$ denote significance at the $1 \%, 5 \%$, and $10 \%$ levels, respectively. In columns (1) to (3), the regressor "U.S. allies" refers to the countries that deployed troops in both Afghanistan and Iraq, while in columns (4) to (6), it refers to the countries that deployed troops in Afghanistan or Iraq or both. 
Table 4: The effect of the post-9/11 terror threat on human rights (pre-9/11 U.S. allies)

\begin{tabular}{|c|c|c|c|c|c|c|}
\hline & \multicolumn{3}{|c|}{ Nato } & \multicolumn{3}{|c|}{ Nato Plus } \\
\hline & $\begin{array}{l}\text { pters } \\
(1)\end{array}$ & $\begin{array}{l}\text { ptera } \\
(2)\end{array}$ & $\begin{array}{l}\text { physint } \\
\text { (3) }\end{array}$ & $\begin{array}{l}\text { pters } \\
(4)\end{array}$ & $\begin{array}{l}\text { ptera } \\
(5)\end{array}$ & $\begin{array}{l}\text { physint } \\
\text { (6) }\end{array}$ \\
\hline U.S. allies & $\begin{array}{l}-0.50^{* *} \\
(0.22)\end{array}$ & $\begin{array}{l}-0.47^{* *} \\
(0.22)\end{array}$ & $\begin{array}{l}-0.49^{* * *} \\
(0.16)\end{array}$ & $\begin{array}{l}-0.29 * * * \\
(0.09)\end{array}$ & $\begin{array}{l}-0.23^{* * *} \\
(0.08)\end{array}$ & $\begin{array}{l}-0.25^{* * *} \\
(0.08)\end{array}$ \\
\hline$(2001-2006)$ & $\begin{array}{l}0.28^{* * *} \\
(0.05)\end{array}$ & $\begin{array}{l}0.04 \\
(0.04)\end{array}$ & $\begin{array}{l}0.09^{* *} \\
(0.04)\end{array}$ & $\begin{array}{l}0.26^{* * *} \\
(0.05)\end{array}$ & $\begin{array}{l}0.04 \\
(0.05)\end{array}$ & $\begin{array}{l}0.07 \\
(0.05)\end{array}$ \\
\hline U.S. allies * (2001-2006) & $\begin{array}{l}0.27^{*} \\
(0.16)\end{array}$ & $\begin{array}{l}0.53^{* *} \\
(0.22)\end{array}$ & $\begin{array}{l}0.16^{*} \\
(0.10)\end{array}$ & $\begin{array}{l}0.20^{* *} \\
(0.08)\end{array}$ & $\begin{array}{l}0.20^{* *} \\
(0.10)\end{array}$ & $\begin{array}{l}0.15^{* *} \\
(0.07)\end{array}$ \\
\hline$\Delta$ prob. $\left(y_{i, t}=0\right)$ & & & $-6.4^{*}$ & & & $-5.8^{* *}$ \\
\hline$\Delta$ prob. $\left(y_{i, t}=1\right)$ & $-6.8^{*}$ & $-19.4^{* *}$ & 3.8 & $-6.1^{* *}$ & $-7.4^{* *}$ & $2.7^{*}$ \\
\hline$\Delta$ prob. $\left(y_{i, t}=2\right)$ & $6.7^{*}$ & $18.1^{* *}$ & $2.0^{*}$ & $5.9^{* *}$ & $6.9^{* *}$ & $2.2^{* *}$ \\
\hline$\Delta$ prob. $\left(y_{i, t}=3\right)$ & 0.1 & $1.3^{* *}$ & 0.5 & $0.2^{* *}$ & $0.5^{* *}$ & $0.7^{* *}$ \\
\hline$\Delta$ prob. $\left(y_{i, t}=4\right)$ & 0.0 & 0.0 & 0.1 & 0.0 & 0.0 & $0.1^{* *}$ \\
\hline$\Delta$ prob. $\left(y_{i, t}=5\right)$ & 0.0 & 0.0 & 0.0 & 0.0 & 0.0 & $0.0^{*}$ \\
\hline$\Delta$ prob. $\left(y_{i, t}=6\right)$ & & & 0.0 & & & $0.0^{*}$ \\
\hline$\Delta$ prob. $\left(y_{i, t}=7\right)$ & & & 0.0 & & & 0.0 \\
\hline$\Delta$ prob. $\left(y_{i, t}=8\right)$ & & & 0.0 & & & 0.0 \\
\hline Human rights violations ${ }_{t-1}$ & $\begin{array}{l}1.02^{* * *} \\
(0.05)\end{array}$ & $\begin{array}{l}0.86^{* * *} \\
(0.05)\end{array}$ & $\begin{array}{l}0.43^{* * *} \\
(0.02)\end{array}$ & $\begin{array}{l}1.02^{* * *} \\
(0.05)\end{array}$ & $\begin{array}{l}0.87^{* * *} \\
(0.05)\end{array}$ & $\begin{array}{l}0.43^{* * *} \\
(0.02)\end{array}$ \\
\hline Human rights violations $_{t-2}$ & $\begin{array}{l}0.53^{* * *} \\
(0.04)\end{array}$ & $\begin{array}{l}0.47^{* * *} \\
(0.04)\end{array}$ & $\begin{array}{l}0.21^{* * *} \\
(0.02)\end{array}$ & $\begin{array}{l}0.54^{* * *} \\
(0.04)\end{array}$ & $\begin{array}{l}0.47^{* * *} \\
(0.04)\end{array}$ & $\begin{array}{l}0.21^{* * *} \\
(0.02)\end{array}$ \\
\hline GDP per capita $(\log )$ & $\begin{array}{l}-0.10^{* * *} \\
(0.02)\end{array}$ & $\begin{array}{l}-0.06^{* *} \\
(0.02)\end{array}$ & $\begin{array}{l}-0.10^{* * *} \\
(0.03)\end{array}$ & $\begin{array}{l}-0.09^{* * *} \\
(0.02)\end{array}$ & $\begin{array}{l}-0.05^{* *} \\
(0.02)\end{array}$ & $\begin{array}{l}-0.10^{* * *} \\
(0.02)\end{array}$ \\
\hline GDP per capita growth & $\begin{array}{l}-1.08^{* *} \\
(0.49)\end{array}$ & $\begin{array}{l}-1.36^{* * *} \\
(0.50)\end{array}$ & $\begin{array}{l}-0.46 \\
(0.42)\end{array}$ & $\begin{array}{l}-0.99^{* *} \\
(0.48)\end{array}$ & $\begin{array}{l}-1.34^{* * *} \\
(0.50)\end{array}$ & $\begin{array}{l}-0.36 \\
(0.42)\end{array}$ \\
\hline Democracy & $\begin{array}{l}-0.04^{* * *} \\
(0.01)\end{array}$ & $\begin{array}{l}-0.03^{* * *} \\
(0.01)\end{array}$ & $\begin{array}{l}-0.04^{* * *} \\
(0.01)\end{array}$ & $\begin{array}{l}-0.05^{* * *} \\
(0.01)\end{array}$ & $\begin{array}{l}-0.03^{* * *} \\
(0.01)\end{array}$ & $\begin{array}{l}-0.04^{* * *} \\
(0.01)\end{array}$ \\
\hline Population (log) & $\begin{array}{l}0.13^{* * *} \\
(0.02)\end{array}$ & $\begin{array}{l}0.09^{* * *} \\
(0.02)\end{array}$ & $\begin{array}{l}0.15^{* * *} \\
(0.02)\end{array}$ & $\begin{array}{l}0.13^{* * *} \\
(0.02)\end{array}$ & $\begin{array}{l}0.09^{* * *} \\
(0.02)\end{array}$ & $\begin{array}{l}0.13^{* * *} \\
(0.02)\end{array}$ \\
\hline Civil war & $\begin{array}{l}0.66^{* * *} \\
(0.13)\end{array}$ & $\begin{array}{l}0.57^{* * *} \\
(0.10)\end{array}$ & $\begin{array}{l}0.60^{* * *} \\
(0.08)\end{array}$ & $\begin{array}{l}0.65^{* * *} \\
(0.12)\end{array}$ & $\begin{array}{l}0.56^{* * *} \\
(0.10)\end{array}$ & $\begin{array}{l}0.58^{* * *} \\
(0.08)\end{array}$ \\
\hline Observations & 3418 & 2680 & 2968 & 3418 & 2680 & 2968 \\
\hline Treatment observations & 96 & 68 & 101 & 299 & 256 & 292 \\
\hline Pseudo R-squared & 0.48 & 0.36 & 0.31 & 0.48 & 0.36 & 0.31 \\
\hline
\end{tabular}

Notes: For each regressor we report the estimated coefficient from the ordered probit model and the robust standard error of the coefficient clustered by country. For the regressor "U.S. allies * (2001-2006)" we also report the change in the probability of each outcome (in \% points) if the regressor increases from 0 to $1 .{ }^{* * *},{ }^{* *}$, and ${ }^{*}$ denote significance at the $1 \%, 5 \%$, and $10 \%$ levels, respectively. In columns (1) to (3), the regressor "U.S. allies" refers to NATO members in 2000, while in columns (4) to (6), it refers to either NATO or Euro-Atlantic Partnership Council members, major non-NATO U.S. allies, or bilateral U.S. allies (all in 2000). 
Table 5: The effect of the post-9/11 terror threat conditional on counter-majoritarian checks

\begin{tabular}{|c|c|c|c|c|c|c|}
\hline & \multicolumn{3}{|c|}{ troops Afghanistan or Iraq } & \multicolumn{3}{|c|}{ Nato Plus } \\
\hline & pters & pters & pters & pters & pters & pters \\
\hline & $(1)$ & $(2)$ & $(3)$ & $(4)$ & (5) & $(6)$ \\
\hline \multirow[t]{2}{*}{ U.S. allies } & $-0.51 * * *$ & $-0.48 * * *$ & -0.05 & $-0.52^{* * *}$ & $-0.52^{* * *}$ & -0.09 \\
\hline & $(0.15)$ & $(0.14)$ & $(0.18)$ & $(0.17)$ & $(0.19)$ & $(0.16)$ \\
\hline \multirow[t]{2}{*}{$(2001-2006)$} & 0.14 & 0.16 & $0.45^{* * *}$ & $0.20^{*}$ & $0.22^{*}$ & $0.41^{* * *}$ \\
\hline & $(0.11)$ & $(0.12)$ & $(0.11)$ & $(0.12)$ & $(0.13)$ & $(0.11)$ \\
\hline \multirow[t]{2}{*}{ U.S. allies * (2001-2006) } & $0.50^{* * *}$ & $0.46^{* *}$ & -0.16 & $0.40^{* *}$ & $0.34^{*}$ & -0.05 \\
\hline & $(0.18)$ & $(0.19)$ & $(0.16)$ & $(0.19)$ & $(0.20)$ & $(0.16)$ \\
\hline \multirow[t]{2}{*}{ U.S. allies * $(2001-2006) * \mathrm{ijr}$} & $-0.67 * * *$ & & & $-0.46^{*}$ & & \\
\hline & $(0.22)$ & & & $(0.24)$ & & \\
\hline \multirow[t]{2}{*}{ Indep. judicial review (ijr) } & $-0.24^{* *}$ & & & $-0.16^{*}$ & & \\
\hline & $(0.10)$ & & & $(0.09)$ & & \\
\hline \multirow[t]{2}{*}{ U.S. allies * ijr } & $0.52^{* *}$ & & & $0.41^{*}$ & & \\
\hline & $(0.22)$ & & & $(0.23)$ & & \\
\hline \multirow[t]{2}{*}{$(2001-2006) * \mathrm{ijr}$} & $0.29 * *$ & & & 0.19 & & \\
\hline & $(0.15)$ & & & $(0.16)$ & & \\
\hline \multirow[t]{2}{*}{ Human rights violations $_{t-1}$} & $1.18^{* * *}$ & $1.14^{* * *}$ & $1.20^{* * *}$ & $1.18^{* * *}$ & $1.14^{* * *}$ & $1.20^{* * *}$ \\
\hline & $(0.07)$ & $(0.09)$ & $(0.11)$ & $(0.07)$ & $(0.09)$ & $(0.11)$ \\
\hline \multirow[t]{2}{*}{ Human rights violations $_{t-2}$} & $0.63^{* * *}$ & $0.62^{* * *}$ & $0.63^{* * *}$ & $0.62^{* * *}$ & $0.60^{* * *}$ & $0.63^{* * *}$ \\
\hline & $(0.06)$ & $(0.09)$ & $(0.09)$ & $(0.07)$ & $(0.09)$ & $(0.09)$ \\
\hline \multirow[t]{2}{*}{ GDP per capita (log) } & $-0.12^{* * *}$ & $-0.11^{* *}$ & $-0.18^{* * *}$ & $-0.09 * *$ & -0.06 & $-0.18^{* * *}$ \\
\hline & $(0.04)$ & $(0.05)$ & $(0.06)$ & $(0.03)$ & $(0.05)$ & $(0.05)$ \\
\hline \multirow[t]{2}{*}{ GDP per capita growth } & $-2.27 * * *$ & $-3.86^{* * *}$ & -1.08 & $-2.28 * * *$ & $-3.77 * * *$ & -1.13 \\
\hline & $(0.88)$ & $(1.48)$ & $(0.97)$ & $(0.88)$ & $(1.42)$ & $(0.96)$ \\
\hline \multirow[t]{2}{*}{ Democracy } & $-0.03^{* * *}$ & $-0.03^{* *}$ & -0.02 & $-0.03^{* * *}$ & $-0.04^{* *}$ & -0.01 \\
\hline & $(0.01)$ & $(0.01)$ & $(0.02)$ & $(0.01)$ & $(0.02)$ & $(0.02)$ \\
\hline \multirow[t]{2}{*}{ Population (log) } & $0.11^{* * *}$ & $0.17^{* * *}$ & 0.03 & $0.12^{* * *}$ & $0.19^{* * *}$ & 0.03 \\
\hline & $(0.04)$ & $(0.04)$ & $(0.07)$ & $(0.04)$ & $(0.05)$ & $(0.07)$ \\
\hline \multirow[t]{2}{*}{ Civil war } & $0.52^{* * *}$ & $0.66^{* * *}$ & $0.55^{* *}$ & $0.50^{* * *}$ & $0.62^{* * *}$ & $0.55^{* *}$ \\
\hline & $(0.16)$ & $(0.19)$ & $(0.23)$ & $(0.16)$ & $(0.19)$ & $(0.22)$ \\
\hline Indep. judicial review (ijr) & 0 or 1 & 0 & 1 & 0 or 1 & 0 & 1 \\
\hline Observations & 1686 & 934 & 752 & 1688 & 936 & 752 \\
\hline Treatment obs. with $\mathrm{ijr}=1$ & 66 & - & 66 & 66 & - & 66 \\
\hline Treatment obs. with $\mathrm{ijr}=0$ & 102 & 102 & - & 95 & 95 & - \\
\hline Pseudo R-squared & 0.56 & 0.57 & 0.54 & 0.56 & 0.57 & 0.54 \\
\hline
\end{tabular}

Notes: "ijr" stands for independent judicial review. For each regressor we report the estimated coefficient from the ordered probit model and the robust standard error of the coefficient clustered by country. ${ }^{* * *}$, **, and $*$ denote significance at the $1 \%, 5 \%$, and $10 \%$ levels, respectively. 


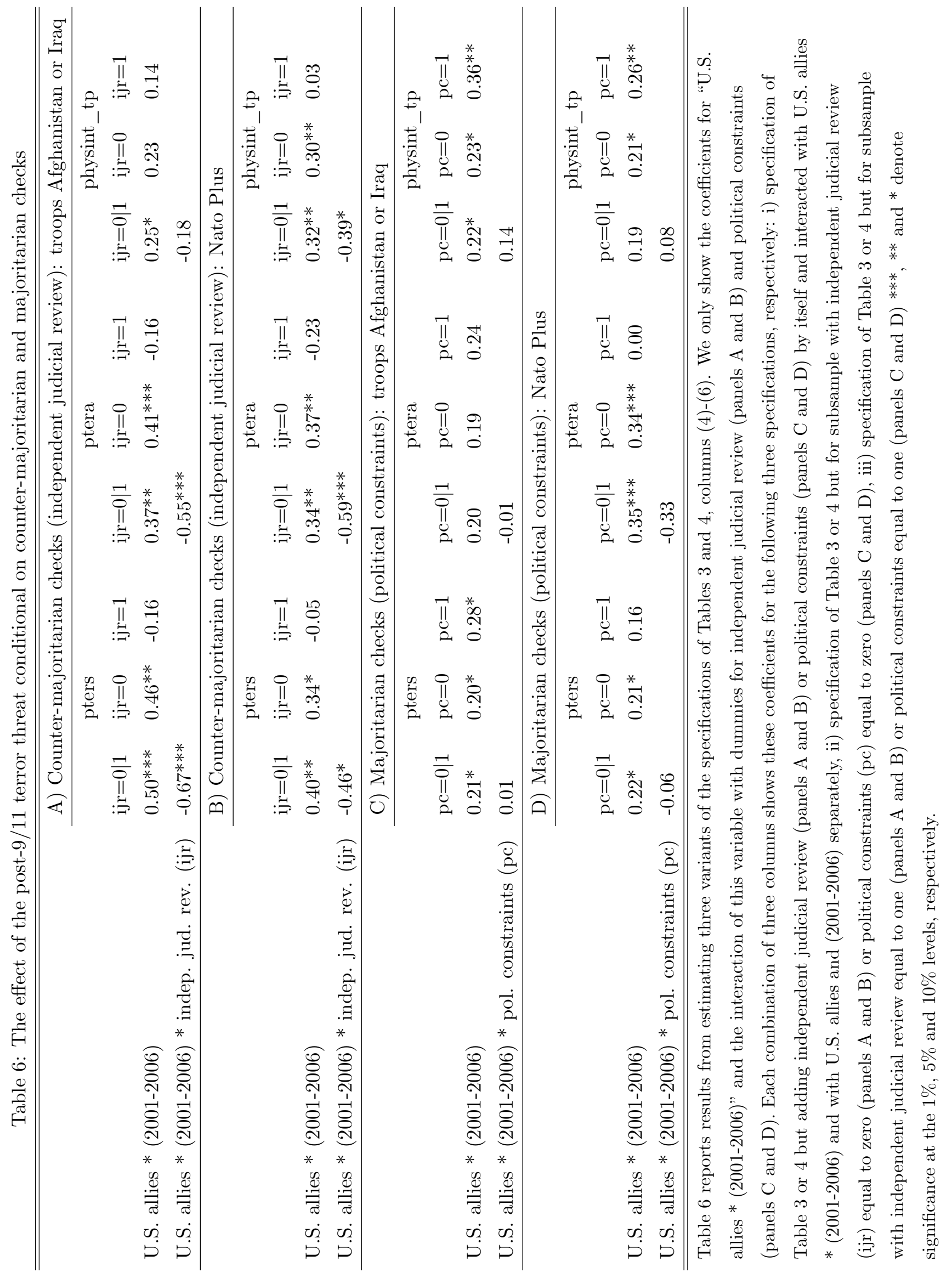



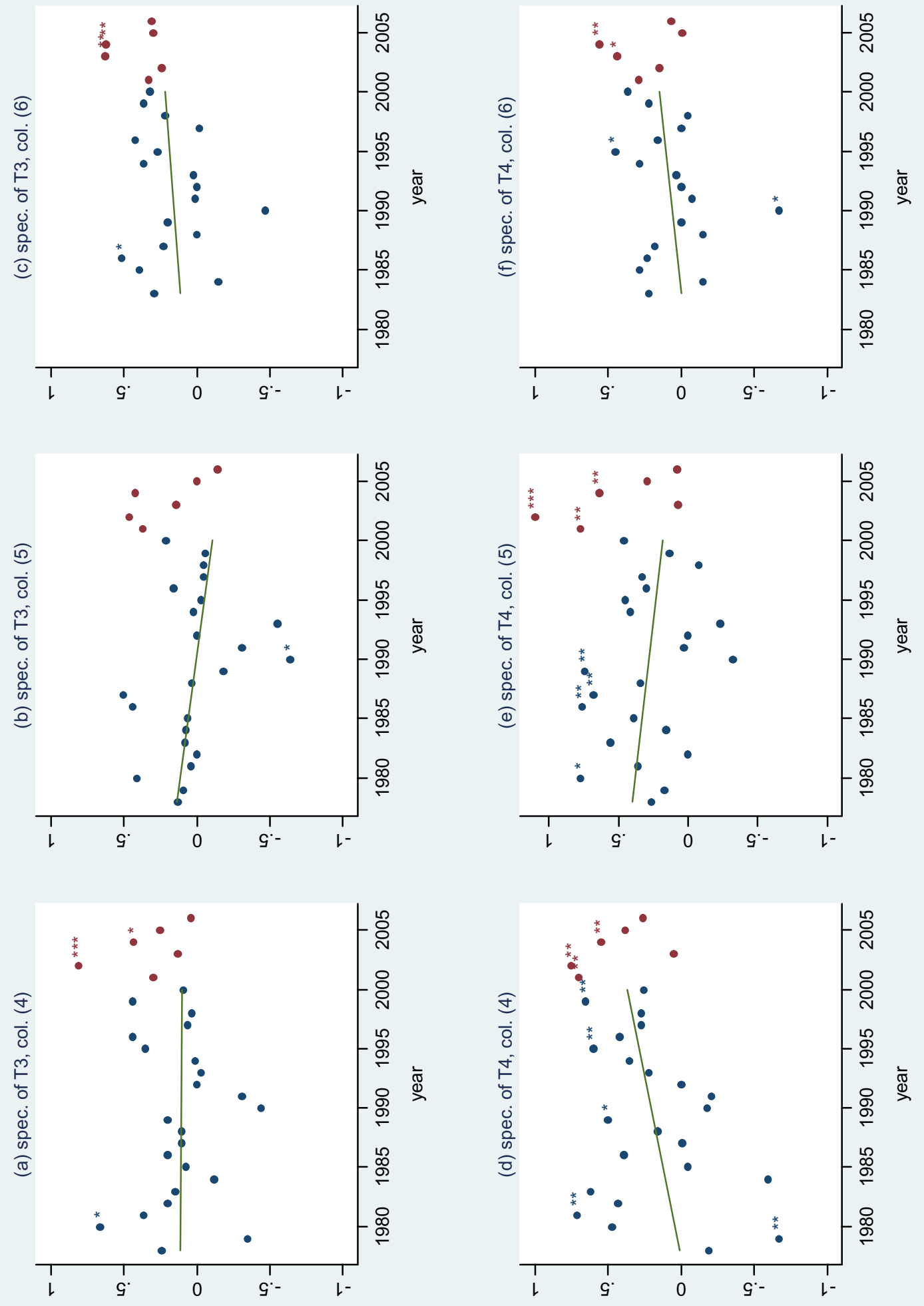

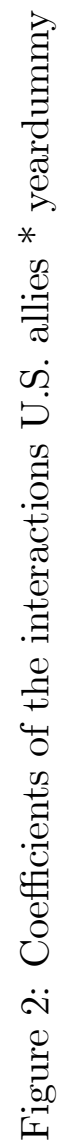

